\title{
The Effect of Foreign Institutional Ownership on Corporate Tax Avoidance: International Evidence
}

\begin{abstract}
We find robust evidence that foreign institutional investors are negatively associated with their investee firms' tax avoidance. To mitigate endogeneity concerns, we apply three identification strategies. First, we implement a two-stage least squares model. Second, we perform a difference-in-differences analysis by exploiting China's legal reform, Qualified Foreign Institutional Investors program, as a quasi-natural experiment. Third, we compare changes in corporate tax avoidance in response to a significant increase in FIIs. We further find that the negative association is dominated by FIIs from countries with high tax morale and FIIs from countries with strong shareholder protection. Finally, we find that the extent of tax morale and shareholder protection in the country where an investee firm is located also matters. We conclude that FIIs play an active role in shaping investee firms' corporate tax avoidance policy.
\end{abstract}

JEL classification: G23, G32, H26, M41

Keywords: Tax Avoidance, Foreign Institutional Ownership, Tax Morale, Shareholder Protection 


\section{INTRODUCTION}

This paper examines whether foreign institutional investors (FIIs) affect their investee firms' tax avoidance. With financial globalization, FIIs have become increasingly important financing sources worldwide. According to the International Monetary Fund (IMF), total investment in equity assets by foreign investors rose more than sevenfold since 1990. The rapid growth of cross-border institutional investment has spurred considerable attention to the roles that FIIs play in their investee firms. An emerging literature finds that, through either direct interventions or indirect supply-demand threats, FIIs significantly influence their investee firms' corporate decisions, including cross-border mergers and acquisitions (Ferreira, Massa, and Matos 2010), corporate governance (Aggarwal, Erel, Ferreira, and Matos 2011), and global accounting comparability (Fang, Maffett, and Zhang 2015).

Since Hanlon and Heitzman (2010)'s call for more research on corporate tax avoidance, there are an increasing number of studies that examine how ownership structures affect corporate tax avoidance from traditional agency theory perspective (e.g., Chen, Chen, Cheng, and Shevlin 2010; Cheng, Huang, Li, and Stanfield 2012; Badertscher, Katz, and Rego 2013; McGuire, Wang, and Wilson 2014). Meanwhile, borrowing from the sociology and the economic literature, a new stream of studies explore how corporate tax avoidance is affected by various social norms, such as religious norms (Boone, Khurana, and Raman 2012) and civic norms (Hasan, Hoi, Wu, and Zhang 2016). Furthermore, DeBacker, Heim, and Tran (2015) show that corporations with owners from countries with higher corruption norms avoid more taxes in the U.S., indicating that certain norms could have a cross-border impact on corporate tax avoidance.

Compared to domestic institutional investors (DIIs), FIIs may come from a country with different extralegal institutions (e.g., tax morale) and/or different legal institutions (e.g., shareholder protection). These different social norms and accustomed governance practices 
could affect FIIs' attitudes towards their investee firms' tax avoidance behaviors. Given that FIIs have motivations and abilities to play an active role in influencing investee firms' decisionmaking process because of their independent position and international visibility (e.g., Gillan and Starks 2003; Aggarwal et al. 2011), it is natural to expect that FIIs could influence their investee firms' tax avoidance decision to reflect FIIs' social norms and accustomed governance practices of their home countries.

Coffee (2001) and Dyck and Zingales (2004) point out that extralegal institutions, such as social norms, can be important to govern corporate behaviors. Economic literature has documented that tax morale, a tax-related social norm, plays an important role in reducing tax evasion at both the individual level and the country level (e.g., Alm and Torgler 2006; Richardson 2006). We conjecture that this intrinsic value of FIIs does not disappear when they invest in a different country. Instead, FIIs could use their influence on their investee firms to make their social norms spillover to a foreign company. Therefore, we expect that FIIs' tax morale is an important mechanism through which FIIs affect their investee firms' tax avoidance.

The influence of FIIs on tax avoidance could also result from their promotion of better governance. La Porta, Lopez-de-Silanes, Shleifer, and Vishny (2000) point out that shareholder protection is crucial to corporate governance, and they document a significant relation between strong shareholder protection and effective corporate governance. In line with this argument, Leuz, Nanda, and Wysocki (2003) find that strong shareholder protection reduces earnings management, and Atwood, Drake, Myers, and Myers (2012) document a negative impact of shareholder protection on corporate tax avoidance. The literature suggests that good governance practices to protect shareholders can be exported by FIIs to their investee firms. Specifically, Aggarwal et al. (2011) find that FIIs from countries with strong shareholder protection promote better corporate governance of their investee firms. Therefore, we expect 
that FIIs' accustomed governance practices are another mechanism through which FIIs affect their investee firms' tax avoidance.

Using a sample of 47,749 firm-year observations across 32 countries between 2000 and 2008, we find that there is a significantly negative relation between FIIs and corporate tax avoidance. The result is also economically significant. Specifically, the coefficient estimate of FIIs translates into corporate tax avoidance decreasing by, on average, 0.46 percentage points (a 9\% decrease in relative terms based on the mean value of tax avoidance) when foreign institutional ownership increases from $0.25 \%$ (the $25^{\text {th }}$ percentile in our sample) to $6.09 \%$ (the $75^{\text {th }}$ percentile in our sample). Given our sample's mean value of pretax income being US\$201.27 million, this $0.46 \%$ decrease in tax avoidance equates to an increase of US\$0.93 million in tax expenses for an average investee firm in our sample.

We conduct a battery of tests to show the robustness of our finding. Since our study is at the international level, the result may be driven by some omitted country-level characteristics instead of FIIs. To mitigate this concern, we add seven additional country-level controls (e.g., freedom from corruption, political transparency, regulation quality, and economic development) to the baseline model and we find that our main result holds.

It is also possible that FIIs choose firms with lower tax avoidance to invest, rather than that FIIs affect investee firms' tax avoidance through their interventions or threats after investment. To mitigate this endogeneity concern, we conduct three different sets of tests. First, following Ferreira et al. (2010), we implement a two-stage least squares model using Morgan Stanley Capital International Index as an instrumental variable for FIIs. Second, we perform a difference-in-differences analysis by exploiting China's legal reform, Qualified Foreign Institutional Investors program, which significantly attracts FIIs to the Chinese stock market, as a quasi-natural experiment. Third, we compare changes in corporate tax avoidance in response to a significant increase (no less than one standard deviation) in foreign institutional 
ownership. The results from all three sets of tests are consistent with that the direction of the effect is from FIIs to investee firms' tax avoidance.

Since we argue that the impact of FIIs on their investee firms' tax avoidance results from their different exposure to extralegal institutions (tax morale) and legal institutions (shareholder protection), we conduct channel tests to provide supportive evidence on our arguments. We find that 1) FIIs from countries with high tax morale play a dominant role in reducing investee firms' tax avoidance; 2) FIIs from countries with strong shareholder protection decrease investee firms' corporate tax avoidance, whereas FIIs from countries with weak shareholder protection do not. These findings lend support to our arguments that tax morale and good governance practices are plausibly underlying channels through which FIIs affect corporate tax avoidance.

Finally, we find that the extent of tax morale and shareholder protection in the country where an investee firm is located also matters. Specifically, we find that DIIs play a dominant role in reducing tax avoidance of investee firms that are located in countries with high tax morale (strong shareholder protection), while for investee firms that are located in countries with low tax morale (weak shareholder protection), only FIIs who are from countries with high tax morale (strong shareholder protection) play a significant role. These additional analyses suggest that the impact of FIIs on investee firms' tax avoidance is not homogenous, and it depends on the relative strength of the extralegal and legal environment between the FIIs' home countries and their investee firm's home countries.

Our paper makes several contributions to the literature. First, our paper is the first to establish a direct effect of FIIs, unique and increasingly important institutional investors, on their investee firms' tax avoidance. Differing from prior studies that mainly focus on how incentives/payoffs of different ownership structures affect investee firms' tax avoidance within the country, our paper examines how institutional investors from other countries can transfer 
their home-country tax norms and accustomed governance practices to their investee firms, and thereby impact investee firms' tax avoidance decision. Thus, our paper complements the literature that examines the impacts of ownership structures on corporate tax avoidance and provides new insights to understand the determinants of tax avoidance from a global financial market perspective.

Second, we provide evidence of two specific channels - tax morale and governance practices - through which FIIs influence investee firms' tax avoidance. Our results add to the new stream of literature that examines the effect of social norms on corporate tax avoidance (e.g., Boone et al. 2012; DeBacker et al. 2015; Hasan et al. 2016). We provide evidence of a previously undocumented spillover effect of tax related social norms, tax morale, through FIIs on investee firms' tax avoidance. We also provide further evidence that is consistent with Aggarwal et al. (2011) that good governance practices (e.g., shareholder protection) do travel around the world.

Third, our paper contributes to the literature by illustrating FIIs' role in corporate policies. Extant literature shows that FIIs affect firm value and performance (Ferreira and Matos 2008), financial reporting practices (Fang et al. 2015), corporate governance (Aggarwal et al. 2011), and innovation (Luong, Moshirian, Nguyen, Tian, and Zhang 2016). Our study extends this stream of research by showing FIIs' effect on investee firms' corporate tax avoidance decision, one of the most important corporate decisions which has received considerable attention from regulators and policymakers internationally. ${ }^{1}$ Our results have important implications for firms with FIIs, investors in the global market, regulators, and policymakers around the world.

\footnotetext{
${ }^{1}$ For example, deterring corporate tax avoidance has been one of the core issues at the Group of Twenty (G20) summits for the last several years.
} 
The rest of our paper is organized as follows. Section II reviews prior literature and develops our hypothesis. Section III describes data in the sample, followed by the outline of our research design and analyses in Section IV. Section V concludes the paper.

\section{PRIOR LITERATURE AND HYPOTHESIS DEVELOPMENT}

Prior literature on the determinants of corporate tax avoidance typically focuses on country characteristics and firm characteristics. The literature on country-level determinants of tax avoidance (e.g., Hanlon, Maydew, and Shevlin 2008; Atwood et al. 2012; Li, Maydew, Willis, and $\mathrm{Xu} 2016$ ) usually focuses on whether certain country characteristics, such as tax system, law enforcement, and political uncertainty, affect corporate tax avoidance within that country. The literature (e.g., Chen et al. 2010; Armstrong, Blouin, and Larker 2012) on firmlevel determinants of tax avoidance has grown rapidly in the last decade. One strand of the literature that is closely related to our study is the impact of ownership structures, such as family ownership, hedge fund ownership, and dual-class ownership, on tax avoidance (e.g., Chen et al. 2010; Cheng et al. 2012; Badertscher et al. 2013; McGuire et al. 2014). In general, these papers study tax avoidance from a traditional agency theory perspective and are motivated by incentives/payoffs of different ownership structures.

Frey (1997) argues that a taxpayer's decision to pay tax is affected by both extrinsic (e.g., potential penalty for tax avoidance) and intrinsic (e.g., tax morale) motivations. Coffee (2001) and Dyck and Zingales (2004) point out that extralegal institutions, such as social norms, can be important to govern corporate behaviors. Recent studies have begun to examine how corporate tax avoidance is affected by social norms, which are incremental to traditional firmlevel and country-level factors. Specifically, Boone et al. (2012) find a significant impact of religious norms on corporate tax avoidance. Hasan et al. (2016) study the effect of civic norms on corporate tax avoidance, and they find that the levels of civic norms in US counties are 
negatively related to tax avoidance activities of corporations with headquarters located in those counties. DeBacker et al. (2015) find that corporations with owners from countries with higher corruption norms avoid more taxes in the U.S. Although informative, these papers do not study the direct impact of tax-related social norms, tax morale, on corporate tax avoidance, and do not investigate whether tax morale can be exported from one country to another.

A taxpayer's intrinsic morale to pay taxes is crucial to his/her tax avoidance decision and it can go beyond the legal enforcement (Luttmer and Singhal 2014). Prior economic literature shows that tax morale as a social norm plays an important role in reducing tax evasion at both the individual level and the country level (e.g., Alm and Torgler 2006; Richardson 2006). We conjecture that the intrinsic tax morale of FIIs does not disappear when they invest in different countries. Instead, FIIs could use their influence on their investee firms to make their intrinsic value spillover to foreign companies.

Another channel we expect that could affect investee firms' tax avoidance is the strength of FIIs' home-country shareholder protection. Shareholder protection is crucial for the effectiveness of corporate governance (La Porta et al. 2000). Leuz et al. (2003) argue that strong shareholder protection limits insiders' ability to acquire private control benefits, which reduces their incentives to mask firm performance through earnings management. Both empirical and survey evidence shows that tax avoidance is also a very important strategy that firms employ to achieve their financial reporting purpose (e.g., Desai and Dharmapala 2006; Frank, Lynch, and Rego 2009; Graham, Hanlon, Shevlin, and Shroff 2014). In a recent study, Atwood et al. (2012) find that strong shareholder protection deters corporate tax avoidance activities.

Aggarwal et al. (2011) show that FIIs promote good corporate governance, especially those FIIs who are from countries with strong shareholder protection (i.e., common-law countries). Their result suggests that FIIs from countries with strong shareholder protection could get accustomed to good corporate governance practices. Thus, when they invest in 
foreign firms, they could diffuse those effective governance practices to their investee firms. ${ }^{2}$ ${ }^{3}$ Therefore, to the extent that FIIs bring governance practices (e.g., shareholder protection) from their home countries to investee firms, we expect that FIIs could impact their investee firms' tax avoidance through this channel.

Prior literature shows that FIIs have capacities to influence their investee firms' behaviors through either direct interventions or indirect supply-demand threats (e.g., Gillan and Starks 2003; Ferreira and Matos 2008; Aggarwal et al. 2011). Gillan and Starks (2003) argue that FIIs are likely to play an important and active role in promoting governance change due to their independent position and international visibility. Prior literature has shown that FIIs aggressively extend their investment globally, thereby increasing their role in corporate decision-making process. For instance, FIIs encourage firms to engage in cross-border mergers and acquisitions (Ferreira et al. 2010), promote improvement in corporate governance (Aggarwal et al. 2011), increase accounting comparability across international financial markets (Fang et al. 2015), and encourage innovation (Luong et al. 2016).

In sum, to the extent that FIIs' country-level tax morale and accustomed governance practices affect FIIs' attitudes towards investee firms' tax avoidance and that FIIs have capacities to influence their investee firms' corporate decisions, we expect that FIIs significantly impact their investee firms' tax avoidance. However, given the fact that FIIs could come from countries with high or low tax morale (strong or weak shareholder protection), we do not predict the dominating effect of FIIs on tax avoidance.

\footnotetext{
2 This diffusion channel works similarly to what is documented in the board interlock literature (e.g., Davis 1991; Palmer, Jennings, and Zhou 1993; Bizjak, Lemmon, and Whitby 2009; Brown and Drake 2014).

${ }^{3}$ A recent survey by International Centre for Pension Management shows that the major concerns that FIIs have when they invest in the developing countries include quality of financial reporting, quality of boards, quality of audits, level of shareholder rights, weak rule of law, and problematic voting procedures.
} 


\section{DATA AND VARIABLE MEASUREMENT}

\subsection{Data}

We obtain data from several sources. International institutional ownership information comes from FactSet/LionShares database. FactSet/LionShares database provides detailed information about institutional investors' holdings, names, types, turnover rates, and headquarter locations, as well as information on their investee firms' prices, shares outstanding, and locations in international capital markets. FactSet/LionShares database collects data of professional money managers, such as mutual funds, pension funds, bank trusts, and insurance companies, directly from public sources, i.e., national regulatory agencies, stock exchanges, industry directories, and company proxies. International institutional ownership studies in the field of accounting and finance have used this dataset as a primary source (e.g., Ferreira and Matos 2008; Aggarwal et al. 2011). A major drawback of this database, however, is that institutional investors report their holdings on different reporting dates with irregular frequency across countries. To address this issue, following Ferreira and Matos (2008), we retain only the latest institutional ownership for each year. Our firm characteristics including tax avoidance information are from Global Compustat, and tax morale index is constructed from the World Values Survey (WVS). The final sample includes 47,749 firm-year observations across 32 countries from 2000 to $2008 .^{4}$

\subsection{Measurements}

\subsubsection{Tax Avoidance Measurement}

Following Atwood et al. (2012), we define tax avoidance as "the reduction of explicit taxes paid" and use the modified cash effective tax rate calculation from Dyreng, Hanlon, and

\footnotetext{
4 At institutional level, we include 2,411 institutional investors headquartered in 43 countries for the corresponding period.
} 
Maydew (2008) as our primary measure of tax avoidance. ${ }^{5}$ The tax avoidance for firm $i$ at year $t$ is calculated as follows:

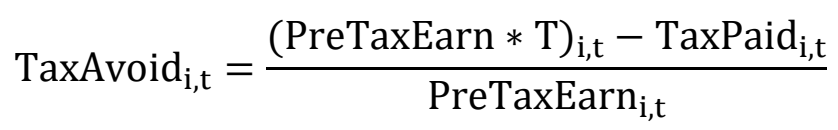

where

PreTaxEarn $=$ pretax earnings less special items

$\mathrm{T}=$ home-country statutory corporate income tax rate

TaxPaid $=$ current cash tax paid $^{6}$

\subsubsection{International Institutional Ownership}

We construct a battery of institutional ownership measures using institutional investors' information. Total institutional ownership, Totown, is aggregate institutional investors' holdings divided by shares outstanding for firm $i$ at year $t$. Foreign institutional ownership, Forown, is aggregate FIIs' holdings divided by shares outstanding for firm $i$ at year $t$. FIIs are defined as institutional investors domiciled in countries different from their investee firms' countries. Foreign institutional ownership coming from countries with high (low) tax morale, Forown_HighMorale (Forown_LowMorale), is the aggregate holdings of FIIs whose home countries are classified as high-(low-) tax-morale countries. Appendix A contains further detailed definitions of other institutional ownership variables.

\footnotetext{
${ }^{5}$ We use annual tax avoidance measurement in our baseline model, instead of the three-year average of tax avoidance used in Atwood et al. (2012), but we construct robustness tests with two-year and three-year averages of tax avoidance. The results are consistent with our baseline result.

${ }^{6}$ Following Atwood et al. (2012), if current cash tax paid is missing, we replace it with total tax expense less deferred tax expense.
} 


\subsubsection{Tax Morale}

The tax morale index is constructed from the World Values Survey (WVS). ${ }^{7}$ The WVS conducts a series of surveys to collect information regarding national culture and/or belief with respect to social, economic, and political issues by interviewing at least 1,000 residents in a given country in almost 100 countries. To assess tax morale, the WVS asks individuals the following question:

"Please tell me for each of the following actions whether you think it can always be justified, never be justified, or something in between: ... Cheating on taxes if you have a chance (on a ten-point scale where 1 is never justifiable and 10 is always justifiable”

WVS data are widely used in many fields such as economics and finance (e.g., Guiso, Sapienza, and Zingales 2003, 2008; Dyck and Zingales 2004; Alm and Torgler 2006). Dyck and Zingales (2004) use the same question in WVS used in our paper as the proxy for the attitude of citizens toward "cheating on taxes" when they examine the association between country characteristics and private benefits of control. We call this attitude of citizens towards "cheating on taxes" tax morale in our paper. ${ }^{8}$ Besides the tax morale questionnaire, other questionnaires in WVS have also been used in the literature. For example, Guiso et al. (2008) use the one questionnaire of trust in WVS to examine the effect of a general lack of trust on stock market participation.

\footnotetext{
${ }^{7}$ Data are available at the webpage via http://www.worldvaluessurvey.org/WVSContents.jsp.

${ }^{8}$ While we define tax avoidance as "the reduction of explicit taxes paid" along a spectrum from low to high aggressiveness, the tax morale measure is more likely to capture the attitude of citizens toward high aggressive tax avoidance by asking the opinions on "cheating on taxes". We argue that if tax morale measure mismatches tax avoidance measure, we should not get any effect of FIIs on tax avoidance through tax morale channel. The fact that we get the results indicates otherwise. In addition, we do not use the continuous tax morale measure. Instead, we separated countries into high and low tax morale based on the median level of tax morale. This should mitigate the noise involved in this measure. Furthermore, as an additional test, we construct high aggressive tax avoidance as our dependent variable and repeat the analysis. We find consistent results.
} 
Based on the above tax morale questionnaire, we follow Alm and Torgler (2006) and construct an individual-level dummy variable that equals 1 if the respondent's answer is 1 (never justifiable) and 0 otherwise. We then take the percentage of a given country's individuallevel tax morale scores as its country-level tax morale index ranging from 0 (lowest degree of tax morale) to 1 (highest degree of tax morale). To include as many countries as possible, we use the most recent three WVS waves (Wave 4, Wave 5, and Wave 6) from 1999 to 2014. If a country participates in more than one waves, we average its tax morale indexes. We then divide the sample into high-tax-morale and low-tax-morale countries, with the cutoff point being the median value of the tax morale index.

\subsubsection{Shareholder Protection}

La Porta et al. (2000) point out that shareholder protection is crucial to the quality of corporate governance. Following Aggarwal et al. (2011), we use legal origin to proxy shareholder protection. La Porta, Lopez-de-Silanes, Shleifer, and Vishny (1998) argue that common-law countries, compared with civil-law countries, have stronger investor protection and therefore higher corporate governance quality. Forown_CommonLaw (Forown_CivilLaw) is the aggregate ownership of FIIs whose home countries are classified as common-law (civillaw) countries.

\subsection{Summary Statistics}

Table 1 presents descriptive statistics on variables used in our empirical analyses. The mean (median) value of tax avoidance is $5.3 \%(6.2 \%)$, similar to Li et al. (2015), who show a mean (median) value of tax avoidance of $6.2 \%$ (9.0\%). Institutional investors hold, on average, $9.4 \%$ of ownership, with approximately $4.7 \%$ foreign institutional ownership and $4.8 \%$ domestic institutional ownership. Our sample firms have average assets of US $\$ 2,368$ million 
and leverage (debt to assets) of $20 \%$. During our sample period, the average corporate tax rate is about $32 \%$ for the 32 countries where investee firms are located. Two thirds of our 32 countries have civil-law legal origin, and approximately $69 \%$ of firms are in developed countries.

\section{[Insert Table 1 here]}

In Table 2, we tabulate tax avoidance and institutional ownership by country. We also divide our sample into two groups: high- and low-tax-morale countries. The mean value of tax avoidance for the high-tax-morale group is $4.7 \%$, and the corresponding value for the low-taxmorale group is $6.1 \%$. The difference in tax avoidance between these two groups is statistically significant at the $1 \%$ level, indicating that firms in high-tax-morale countries are associated with lower levels of tax avoidance. Regarding institutional ownership, both domestic and foreign ownership are higher in low-tax-morale countries than in high-tax-morale countries.

\section{[Insert Table 2 here]}

We further examine the relation between a country's legal origin and tax avoidance. In common-law countries, 5 out of 10 are classified as high-tax-morale countries, compared with 11 out of 22 civil-law countries. We find that the mean value of tax avoidance in common-law countries is $4.0 \%$ and the corresponding value in civil-law countries is $5.5 \%$; the difference between these two groups is statistically significant at the $1 \%$ level. ${ }^{9}$ For brevity, the results are not tabulated.

\footnotetext{
${ }^{9} \mathrm{We}$ find that the mean value of tax avoidance in developed countries is $2.9 \%$ and the corresponding value in developing countries is $9.7 \%$, and the difference between these two groups is statistically significant at the $1 \%$ level.
} 


\section{EMPIRICAL RESULTS}

\subsection{Baseline Regression Results: Foreign Institutional Ownership and Tax Avoidance}

In Table 3, we investigate the effect of institutional ownership on tax avoidance. Our baseline regression model is as follows:

$$
\begin{gathered}
\text { TaxAvoid }_{i, t}=\alpha_{0}+\sum \alpha_{m} \text { InstOWn }_{i, t}+\sum \alpha_{n} \text { Control }_{n}+\alpha_{\text {year }} \\
+\alpha_{\text {industry }}+\alpha_{\text {country }}+\varepsilon_{i, t}
\end{gathered}
$$

where

$\operatorname{Tax}_{\text {Avoid }}, \mathrm{t}=$ tax avoidance measurement from Model (1)

InstOwn $_{\mathrm{i}, \mathrm{t}}=$ types of institutional ownership (e.g., Totown, or Domown and Forown, etc.)

$\alpha_{\text {year }}=$ year fixed effects

$\alpha_{\text {industry }}=$ industry fixed effects

$\alpha_{\text {country }}=$ country fixed effects

Control $=\operatorname{Ln}\left(\right.$ Size $_{i, t-1}$, Leverage $_{i, t}$, ROA $_{i, t}$, Sales $_{\text {Growth }}, t$, $R \& D_{i, t}$, Accrual $_{i, t}$, Tax $_{\text {Rate }}, t, t$

Foreign Operations $s_{i, t}$ (see Appendix A for detailed information)

In Column (1), we first examine the association between tax avoidance and total institutional ownership (Totown). We find that the coefficient on Totown is -0.042 , which is statistically significant at the $1 \%$ level. Economically, our coefficient estimate of Totown translates into corporate tax avoidance decreasing by, on average, $0.51 \%$ (a $10 \%$ decrease in relative terms based on the mean value of tax avoidance) when total institutional ownership increases from $1.18 \%$ (the $25^{\text {th }}$ percentile in our sample) to $13.30 \%$ (the $75^{\text {th }}$ percentile). Given the mean value of pretax income being US $\$ 201.27$ million in our sample, this $0.51 \%$ decrease 
in tax avoidance would equal an increase of US\$1.03 million in tax expenses for an average firm.

\section{[Insert Table 3 here]}

To test how FIIs affect corporate tax avoidance, we split institutional ownership into foreign (Forown) and domestic (Domown) institutional ownership. Column (2) reports the results. We find that the coefficient on Forown is negative and statistically significant at the $1 \%$ level. Economically, the coefficient estimate of FIIs is -0.080 , which translates into corporate tax avoidance decreasing by, on average, $0.46 \%$ (a 9\% decrease in relative terms based on the mean value of tax avoidance) when foreign institutional ownership increases from $0.25 \%$ (the $25^{\text {th }}$ percentile in our sample) to $6.09 \%$ (the $75^{\text {th }}$ percentile). This $0.46 \%$ decrease in tax avoidance would equal a US $\$ 0.93$ million increase in tax expenses by an average firm in our sample. For domestic institutional ownership, although the coefficient on Domown is negative, it is statistically insignificant. Hence our results indicate that foreign institutional ownership plays a dominant role in reducing investee firms' tax avoidance.

\subsection{Robustness Checks}

\subsubsection{Do Home-Country Characteristics Matter?}

Although we use country fixed effects in our baseline regression, our results may still be driven by omitted country characteristics. In Table 4, we examine how various country characteristics could affect our main finding. Extant tax avoidance research builds on the theory that a firm determines its level of tax avoidance by trading off potential benefits from tax savings with potential risks of being caught by the government (Mills 1998). Thus we focus on country characteristics that may affect this trade-off decision. One limitation of international- 
level studies, however, is that proxy variables for certain country characteristics are often neither time-variant nor comprehensive. To overcome this problem, following Rajan and Zingales (1998), we include interaction terms between country and year in our regressions. We thus can test the effect of time-invariant variables, such as legal origin and economic development, while controlling for unobservable heterogeneous cross-country effects that might affect our findings.

We first include four country characteristics that affect the strength of legal enforcement, the likelihood of a firm being audited by the government, and/or the likelihood of it being punished for tax avoidance: legal origin (CivilLaw) from La Porta et al. (1998), government effectiveness to enforce the law (GovEffect), the quality of regulations (RegQuality), and transparency in politics (Accountability). Columns (1) to (4) in Table 4 report the results. We find that three out of the four variables are significantly and negatively associated with tax avoidance at the $1 \%$ level, and CivilLaw is insignificantly associated with tax avoidance. Our results suggest that effective law enforcement and high political transparency reduce local firms' tax avoidance.

[Insert Table 4 here]

We then include an economic development indicator (EconDevelop) that equals 1 for a developed country and 0 otherwise. Prior tax research shows that tax evasion is pervasive in developing countries (e.g., Richupan 1984; Gillis 1989; Bird and de Jantscher 1992). We find that EconDevelop is significantly and negatively associated with tax avoidance at the $1 \%$ level, consistent with prior studies.

We further add an index measuring a country's freedom from corruption (AntiCorruption) obtained from the Heritage Foundation. If corruption is high, marginal benefits 
from tax savings would be greater than marginal cost of punishment imposed on firms for tax avoidance as a result of weak enforcement of tax collection and/or lack of government audits. As predicted, Anti-Corruption is significantly and negatively associated with tax avoidance at the $1 \%$ level. Lastly, we include natural logarithm of the investee firms' home-country tax morale (Ln(Tax Morale Index)), and the coefficient on $\operatorname{Ln}($ Tax Morale Index) is also significantly negative. More importantly, in all seven regressions, Forown stays significantly and negatively associated with tax avoidance at the $1 \%$ level. Furthermore, when we add all the country-characteristics variables in one regression in Column (8), the coefficient on Forown stays significant and negative. Taken together, these results show that our main findings are not subsumed by country-level factors that could affect tax avoidance.

\subsubsection{Two-Stage Least Squares (2SLS) Model}

Our model could suffer from endogeneity. For example, if FIIs prefer to invest in firms overseas with low tax avoidance, firms with low tax avoidance may be more likely to have high foreign institutional ownership. In addition, although we try to include control variables that are found to affect tax avoidance in the literature, our model could still suffer from omitted variable bias. We first test if our variable of interest, Forown, is an exogenous variable in our baseline model. The F-value for our robust regression is 3.28 (p-value is 0.07 ). This result indicates that our variable of interest is endogenous. Thus, the OLS model may be inefficient.

To mitigate endogeneity concerns, we implement a two-stage least squares (2SLS) model with instrumental variable (IV). A good IV is correlated with the endogenous variable and not directly correlated with the dependent variable. It is correlated with the dependent variable only through the endogenous variable. Ferreira and Matos (2008) find that FIIs prefer firms listed in the Morgan Stanley Capital International (MSCI) index. Therefore, following Ferreira et al. (2010), we use MSCI Inclusion as an instrumental variable for foreign 
institutional ownership. MSCI Inclusion equals 1 if a given firm is included in MSCI in a given year $t$ and 0 otherwise. It is not possible to prove that the instrumental variable is correlated with the dependent variable only through the endogenous variable. To test the instrument's validity, we run an F-test and find an F-value of 289.31, indicating that our instrumental variable is valid. In addition, to our best knowledge, there is no theoretical or empirical paper documenting that inclusion in MSCI index affects firms' tax avoidance behaviors.

We then regress tax avoidance on predicted foreign institutional ownership (Pred_Forown) from first-stage regression. Table 5 reports the results. We find that MSCI Inclusion is significantly and positively associated with foreign institutional ownership at the $1 \%$ level. In the second stage, we find that Pred_Forown is significantly and negatively associated with tax avoidance at the $1 \%$ level. This result is consistent with our baseline result, that is, foreign institutional ownership has a significantly negative effect on tax avoidance.

[Insert Table 5 here]

\subsubsection{Quasi-Natural Experiment: China's Qualified Foreign Institutional Investors Reform}

In Table 6, we further address endogeneity concerns by exploiting a quasi-natural experiment. Many stocks traded on Chinese exchanges offer two types of shares, A share and B share. A share is the regular stock, which was available to domestic investors but unavailable to foreign investors before 2002. If foreign investors wanted to invest in mainland China's stock market before 2002, they could purchase stocks only through B shares. B shares have the same rights as A shares except that Type B shareholders receive dividends in foreign currencies (U.S. dollars and Hong Kong dollars). Compared with A shares, the number of B shares was limited. In 2002, China's Qualified Foreign Institutional Investors reform took effect. It allowed qualified FIIs to purchase stocks directly through A shares. This reform attracted more 
FIIs to invest in China's stock market, which provides us with a good quasi-natural experiment setting.

Because our sample starts in 2000 and the reform happened in 2002, we analyze a [ -2 , 2] year window excluding event year, 2002. In an untabulated test, we find that FIIs in China increase by $8.63 \%$ (from $10.38 \%$ to $19.00 \%$ ) after the reform, and this increase is significant at the $1 \%$ level. The result confirms an important assumption of our setting: the number of shares held by FIIs increases significantly after the legal reform.

Our difficulty in conducting a difference-in-differences analysis comes from the fact that there is no perfect control group of countries to match with China. Given the fact that China is a low-tax-morale country, a developing country, and a civil-law country, we choose three different sets of control countries based on those three criteria, respectively. If our results hold for all three sets of control groups, we could be confident that our results are robust.

Table 6 reports the results of difference-in-differences regressions using these three different sets of control countries. Three variables of interest are China, Post-Reform, and China*Post-Reform. China is an indicator that equals 1 if the investee firms' home country is China and 0 otherwise. Post-Reform is an indicator that equals 1 if the observational year is after China's reform year, 2002, and 0 otherwise. China*Post-Reform is the interaction term between China and Reform, capturing the post-reform effect on investee firms in China compared with control countries. The coefficients on our variable of interest, China*Reform, are all negative and significant in Columns (1) to (3), indicating that the significant increase in foreign institutional ownership leads to a decrease in tax avoidance in China compared with benchmark countries.

[Insert Table 6 here] 
Furthermore, we also match China with countries satisfying all of the three criteria: being a low-tax-morale country, being a developing country, and being a civil-law country. The result is reported in Column (4). The coefficient on China*Reform continues to be negative and significant. In sum, our difference-in-differences results mitigate the endogeneity concerns and confirm a causal effect of foreign institutional ownership on tax avoidance.

\subsubsection{The Effect of Significant Changes in Institutional Ownership on Tax Avoidance}

Our third identification strategy is a change regression. Specifically, we test how corporate tax avoidance changes after institutional ownership significantly increases. To ensure a non-negligible effect of changes in foreign (domestic) institutional ownership on corporate tax policy, we first identify firms with an increase in foreign (domestic) institutional ownership by at least one standard deviation from the previous year to the current year: $1,342(1,275)$ unique firms for foreign (domestic) institutional investors. We then find matching firms (i.e., firms that do not have an increase in foreign (domestic) institutional ownership by at least one standard deviation) based on year, industry (i.e., the first three digits of the SIC code), and the nearest firm size ${ }^{10}$. We restrict our analysis to a short window, two years before and after changes in foreign (domestic) institutional ownership, to avoid confounding effects. We also exclude the year when the increase in institutional ownership happens.

Post is a dummy variable that equals 1 for years after foreign (domestic) institutional ownership increases and 0 otherwise. IncFor (IncDom) is a dummy variable that equals 1 for firms with an increase in foreign (domestic) institutional ownership by at least one standard deviation and 0 otherwise. The interaction term between Post and IncFor (IncDom) captures the effect of increased foreign (domestic) institutional ownership between the treatment group

\footnotetext{
${ }^{10}$ The ratio of assets between two firms is bounded by $75 \%$ and $125 \%$.
} 
and the control group. This difference-in-differences approach provides us dynamic views to compare the effect of changes in foreign (domestic) institutional ownership on tax avoidance.

The first pair of models test changes in tax avoidance before and after significant changes in foreign (domestic) institutional ownership relative to corresponding matched firms without control variables. We report the results in Table 7 . We find that the level of tax avoidance decreases after significant increase in foreign (domestic) institutional ownership compared with corresponding matched firms. The coefficient on Post*IncFor (Post*IncDom) is $-0.025(-0.034)$, which are statistically significant at the 5\% (1\%) level. In the next pair, we include control variables used in Table 3. Although the coefficient on Post*IncFor remains statistically and economically significant, the coefficient on Post*IncDom becomes insignificant. This evidence strongly supports our hypothesis that FIIs drive the reduction in investee firms' corporate tax avoidance.

\section{[Insert Table 7 here]}

\subsection{Exploring Underlying Mechanisms}

Until now, we find that FIIs have a significantly negative effect on investee firms' tax avoidance. In hypothesis development section, we conjecture that social norms (tax morale) and accustomed governance practices (shareholder protection) possibly spillover from one country to another through FIIs and therefore result in the effect of FIIs on investee firms' tax avoidance. In this subsection, we investigate these two possible mechanisms that could drive the negative relation between FIIs and corporate tax avoidance.

\subsubsection{Mechanism 1: FIIs' Home-Country Tax Morale and Tax Avoidance}


We first examine the effect of FIIs' home-country tax morale on investee firms' tax avoidance. We separate foreign institutional ownership into two groups based on FIIs' homecountry tax morale: FIIs headquartered in high-tax-morale countries (Forown_HighMorale) and FIIs headquartered in low-tax-morale countries (Forown_LowMorale). In Column (1) of Table 8, we find FIIs headquartered in high-tax-morale countries have a significantly negative impact on investee firms' tax avoidance, whereas FIIs headquartered in low-tax-morale countries is positively (but not significantly) associated with investee firms' tax avoidance. Our findings indicate that FIIs' home-country tax morale plays a critical role in shaping investee firms' tax avoidance.

[Insert Table 8 here]

We further test how investee firms' home-country tax morale affects our findings. In Columns (2) and (3), we examine the effects of Forown on TaxAvoid in low- and high-taxmorale countries separately. We find different effects of FIIs on investee firms located in countries with different levels of tax morale. For investee firms located in low-tax-morale countries, the coefficient on Forown is -0.131 , statistically significant at the $1 \%$ level. For investee firms from high-tax-morale countries, however, the coefficient on Forown becomes insignificant. To illustrate the economic effects, we find that an increase in Forown from $0.14 \%$ (the $25^{\text {th }}$ percentile) to $7.12 \%$ (the $75^{\text {th }}$ percentile) in low-tax-morale countries reduces tax avoidance in investee firms by $0.91 \%$ (a $15 \%$ decrease in relative terms based on the mean value of tax avoidance of investee firms in low-tax-morale countries).

In Columns (4) and (5), we further extend our test to see the effect of relative differences in tax morale between FIIs and their investee firms on tax avoidance. Interestingly, we find that for investee firms located in low-tax-morale countries, having FIIs from high-tax-morale 
countries (Forown_HighMorale) is significantly and negatively associated with tax avoidance (TaxAvoid), but the effect of FIIs from low-tax-morale countries (Forown_LowMorale) is insignificant. For investee firms located in high-tax-morale countries, FIIs do not affect tax avoidance, regardless of whether they are from high- or low-tax-morale countries. Overall, the results indicate that the differences in tax-morale levels between FIIs' home countries and their investee firms' home countries matter, and only FIIs from high-tax-morale countries significantly affect tax avoidance of investee firms located in low-tax-morale countries. Our results provide evidence that FIIs affect investee firms' tax avoidance through the mechanism of tax morale.

\subsubsection{Mechanism 2: FIIs' Home-Country Governance Practices and Tax Avoidance}

In Table 9, we test how FIIs' home-country governance practices (shareholder protection) could influence their investee firms' tax avoidance. Extant literature (e.g., Aggarwal et al. 2011) shows that FIIs from countries with strong shareholder protection enhance corporate governance especially when their investee firms are located in countries with weak shareholder protection and therefore lack external corporate governance mechanisms. Following Aggarwal et al. (2011), we use legal origin to proxy country-level shareholder protection. La Porta et al. (1998) argue that common-law countries, compared with civil-law countries, have stronger investor protection and therefore higher corporate governance quality. Forown_CommonLaw(Forown_CivilLaw) measures aggregate ownership of FIIs whose home countries are classified as common-law (civil-law) countries. We find that FIIs from common-law countries (strong-shareholder-protection countries) have a negative effect on investee firms' tax avoidance, and it is significant at the $1 \%$ level. In contrast, FIIs from civil-law countries (weak-shareholder-protection countries) have a positive effect on investee firms' tax avoidance, but this result is not statistically significant. The results support 
the idea that FIIs' home-country governance practices (shareholder protection) are another plausible mechanism through which FIIs affect their investee firms' tax avoidance.

[Insert Table 9 here]

We further split the sample into two subsamples: investee firms in civil-law countries and investee firms in common-law countries. We find that FIIs have a significantly negative effect on tax avoidance only for investee firms located in civil-law countries, and this negative effect is driven by FIIs from common-law countries. The result suggests that only FIIs from countries with strong shareholder protection affect tax avoidance of investee firms located in countries with weak shareholder protection. The result further confirms that the relative strength of shareholder protection between a FII's home country and its investee firm's home country matters.

Overall, our cross-sectional variation tests in Tables 8 and 9 support that FIIs affect corporate tax avoidance through channels of tax morale and shareholder protection. Our results also suggest that FIIs' effect on corporate tax avoidance is not homogenous, and it depends on the relative strength of tax morale and shareholder protection between FIIs' home countries and their investee firms' home countries.

\subsection{Additional Tests}

\subsubsection{Corruption Norms as an Alternative Explanation}

DeBacker et al. (2015) find that corporations with owners from countries with higher corruption norms avoid more tax in the U.S. An alternative explanation of our finding is that FIIs affect tax avoidance through the channel of corruption norms instead of tax norms. It should be pointed out that when we add both Anti-Corruption and Ln(Tax Morale Index) to the 
baseline regression model together with other country characteristics, we find both coefficients are significant (the coefficient on Anti-Corruption is -0.143 with t-value of -3.84 , and the coefficient on $\operatorname{Ln}($ Tax Morale Index) is -0.065 with t-value of -2.13) as shown in Table 4 Column (8). These results indicate that corruption and tax morale are different constructs, although they both affect tax avoidance.

To further mitigate this concern, we conduct an additional test. Specifically, we use an index measuring a country's freedom from corruption (Anti-Corruption) obtained from the Heritage Foundation and separate countries into high- and low-corruption countries based on the median value. We then separate FIIs into four groups: FIIs from countries with high tax morale and high corruption, FIIs from countries with high tax morale and low corruption, FIIs from countries with low tax morale and high corruption, and FIIs from countries with low tax morale and low corruption. Then, we run a regression of tax avoidance on these four variables of FIIs together with same control variables and fixed effects used in our baseline model. The results are reported in Table 10. We find that only coefficients on FIIs from countries with high tax morale and low corruption and FIIs from countries with high tax morale and high corruption are significantly negative. These results indicate that regardless of corruption levels of FIIs' home countries, it is FIIs' home-country tax morale that drives the decrease in their investee firms' tax avoidance.

\section{[Insert Table 10 here]}

\subsubsection{Investment Horizon and Tax Avoidance}

Khurana and Moser (2013) find that long-term institutional ownership is negatively associated with tax avoidance. Their evidence is broadly consistent with existing institutional ownership literature showing that investors with long-term institutional ownership care more 
about the investee firms' long-term value creation (e.g., Bushee 2001). We also argue that longterm institutional investors put more efforts in monitoring their investee firms and their norms and governance practices are more likely to be reflected in corporate decisions. Therefore, we further examine how FIIs' investment horizon affects the relation between FIIs and tax avoidance.

In Table 11, our main variable of interest is foreign institutional ownership, partitioned by investment horizon: Forown_Long and Forown_Short. We also partition domestic institutional ownership by investment horizon for additional insights. We find long-term foreign institutional ownership (Forown_Long) exhibits significantly negative coefficients at the $1 \%$ level, but short-term foreign institutional ownership (Forown_Short) is not significantly related to TaxAvoid. In addition, long-term domestic institutional ownership (Domown_Long) exhibits a significantly negative coefficient at the 5\% level, whereas short-term domestic institutional ownership (Domown_Short) is significantly and positively related to TaxAvoid at the 5\% level. The results are consistent with Khurana and Moser (2013) and demonstrate that FIIs' investment horizon also matters to their impact on corporate tax avoidance.

[Insert Table 11 here]

\subsubsection{Other Additional Tests}

Finally, we conduct a set of additional analyses. Richupan (1984), Gillis (1989), and Bird and de Jantscher (1992) find empirical evidence that economic development is highly associated with tax morale. In Table 12 Panel A, we use a country's economic development as an alternative proxy for tax morale. We find that FIIs from developed countries have a significantly negative impact on tax avoidance of the investee firms located in developing 
countries, and DIIs have a significantly negative impact on tax avoidance of the investee firms located in developed countries, consistent with the tax morale results.

[Insert Table 12 here]

In Panel B, we further examine the effect of FIIs on aggressive tax avoidance. Since our tax morale measure is constructed from WVS questionnaire on the acceptance of "cheating on taxes", one may argue that the concept of tax morale and tax avoidance measurement used in this paper do not match. To mitigate this concern, we conduct a sensitivity test to examine the impact of FIIs' home-country tax morale on aggressive tax avoidance. Similar to Donohoe and Knechel (2014), we rank tax avoidance by country, industry, and year. TaxAggressive equals 1 if the observation is in the top tercile and 0 otherwise. We continue to find that FIIs, especially FIIs from countries with high tax morale, have a significantly negative impact on aggressive tax avoidance.

In Panel C, we restrict our analysis to G20 member nations, which represent more than $75 \%$ of world trade and $85 \%$ of global GDP. By exclusively examining G20 members, we ensure our findings are economically important. Moreover, we want to show our findings are robust to alternative high- and low-tax-morale countries. In Panel D, we further dissect hightax-morale FIIs into US and non-US FIIs to see if the negative impact of high-tax-morale (common-law) FIIs on tax avoidance is dominated by US FIIs. One may argue that US has a strong impact on economy worldwide. Our results may only be driven by FIIs from US. The result shows that both US and non-US high-tax-morale (common-law) FIIs are negatively associated with tax avoidance in the full sample and in the subsample of low-tax-morale (civillaw) countries; and non-US high-tax-morale (common-law) FIIs' effect is larger in both magnitude and significance. Collectively, our main findings are robust to these additional tests. 


\section{CONCLUSION}

The importance of FIIs in global financial markets has been rising rapidly. In this paper, we examine whether and how FIIs affect their investee firms' corporate tax avoidance. We report robust evidence that FIIs negatively affect their investee firms' tax avoidance. To mitigate endogeneity concerns, we provide a series of analyses (e.g., difference-in-differences tests and 2SLS test with IV) to identify the causal effect of FIIs on their investee firms' corporate tax avoidance.

Moreover, we provide evidence to support that FIIs affect corporate tax avoidance through two plausible mechanisms: FIIs' home-country tax morale and their home-country shareholder protection. Furthermore, we find that the extent of tax morale and shareholder protection in the country where the investee firms are located also matters.

Our paper contributes to the tax avoidance literature by establishing a direct effect of FIIs on investee firms' tax avoidance. It complements the literature on how corporate ownership structures affect tax avoidance and furthers our understanding of the determinants of tax avoidance from the global market perspective. This paper also extends the literature on how social norms affect tax avoidance. We find that social norms, in particular tax morale, can spillover from FIIs' home countries to their investee firms. Furthermore, our paper contributes to the literature by illustrating FIIs' active role in corporate policies. Given the increasing concerns about corporate tax avoidance from regulators and policymakers internationally, our results have important implications for regulators, policymakers, and investors in the global financial market. 


\section{REFERENCES}

Aggarwal, R., I. Erel, M. Ferreira, and P. Matos. 2011. Does governance travel around the world? Evidence from institutional investors. Journal of Financial Economics 100(1):154-181.

Alm, J., and B. Torgler. 2006. Culture differences and tax morale in the United States and in Europe. Journal of Economic Psychology 27(2): 224-246.

Armstrong, C. S., J. L. Blouin, and D. F. Larcker. 2012. The incentives for tax planning. Journal of Accounting and Economics 53(1): 391-411.

Atwood, T. J., M. S. Drake, J. N. Myers, and L. A. Myers. 2012. Home country tax system characteristics and corporate tax avoidance: International evidence. The Accounting Review 87(6): 1831-1860.

Badertscher, B. A., S. P. Katz, and S. O. Rego. 2013. The separation of ownership and control and corporate tax avoidance. Journal of Accounting and Economics 56(2): 228-250.

Bird, R. M., and M. C. de Jantscher, eds. 1992. Improving Tax Administration in Developing Countries (Vol. 19). International Monetary Fund. Washington, DC.

Bizjak, J., M. Lemmon, and R. Whitby. 2009. Option backdating and board interlocks. Review of Financial Studies 22 (11): 4821-4847.

Boone, J. P., I. K. Khurana, and K. K. Raman. 2012. Religiosity and tax avoidance. The Journal of the American Taxation Association 35(1): 53 - 84.

Brown, J. L., and K. D. Drake. 2014. Network ties among low-tax firms. The Accounting Review 89(2): 483-510.

Bushee, B. J. 2001. Do institutional investors prefer near-term earnings over long-run value? Contemporary Accounting Research 18(2): 207-246.

Chen, S., X. Chen, Q. Cheng, and T. Shevlin. 2010. Are family firms more tax aggressive than non-family firms? Journal of Financial Economics 95(1): 41-61.

Cheng, C. S. A., H. H. Huang, Y. Li, and J. Stanfield. 2012. The effect of hedge fund activism on corporate tax avoidance. The Accounting Review 87(5): 1493-1526.

Coffee, J. C. 2001. Do norms matter? A cross-country evaluation. University of Pennsylvania Law Review 149(6): 2151-2177.

Davis, G. F. 1991. Agents without principles? The spread of the poison pill through the intercorporate network. Administrative Science Quarterly 36 (4): 583-613.

DeBacker, J., B. T. Heim, and A. Tran. 2015. Importing corruption culture from overseas: Evidence from corporate tax evasion in the United States. Journal of Financial Economics 117(1): 122-138. 
Desai, M. A., and D. Dharmapala. 2006. Corporate tax avoidance and high-powered incentives. Journal of Financial Economics 79(1): 145-179.

Donohoe, M. P., and R. W. Knechel. 2014. Does corporate tax aggressiveness influence audit pricing? Contemporary Accounting Research 31(1): 284-308.

Dyck, A., and L. Zingales. 2004. Private benefits of control: An international comparison. The Journal of Finance 59(2): 537-600.

Dyreng, S. D., M. Hanlon, and E. L. Maydew. 2008. Long-run corporate tax avoidance. The Accounting Review 83(1): 61-82.

Fang, V. W., M. Maffett, and B. Zhang. 2015. Foreign institutional ownership and the global convergence of financial reporting practices. Journal of Accounting Research 53(3): 593631.

Ferreira, M. A., M. Massa, and P. Matos. 2010. Shareholders at the gate? Institutional investors and cross-border mergers and acquisitions. Review of Financial Studies 23(2): 601-644.

Ferreira, M. A., and P. Matos. 2008. The colors of investors' money: The role of institutional investors around the world. Journal of Financial Economics 88(3): 499-533.

Frank, M. M., L. J. Lynch, and S. O. Rego. 2009. Tax reporting aggressiveness and its relation to aggressive financial reporting. The Accounting Review 84(2): 467 - 496.

Frey, B. S. 1997. Not Just for The Money: An Economic Theory of Personal Motivation. Edward Elgar Publishing. Cheltenham, United Kingdom.

Gillan, S. L., and L. T. Starks. 2003. Corporate governance, corporate ownership, and the role of institutional investors: A global perspective. Journal of Applied Finance 13(2): 4-22.

Gillis, M. 1989. Comprehensive tax reform: the Indonesian experience, 1981-1988. Tax Reform in Developing Countries 1: 79.

Graham, J. R., M. Hanlon, T. J. Shevlin, and N. T. Shroff. 2014. Incentives for tax planning and avoidance: Evidence from the field. The Accounting Review 89(3): 991-1023

Guiso, L., P. Sapienza, and L. Zingales. 2003. People's opium? Religion and economic attitudes. Journal of Monetary Economics 50(1): 225-282.

Guiso, L., P. Sapienza, and L. Zingales. 2008. Trusting the stock market. Journal of Finance 63(6): 2557-2600.

Hanlon, M., and S. Heitzman. 2010. A review of tax research. Journal of Accounting and Economics 50(2): 127-178.

Hanlon, M., E. L. Maydew, and T. Shevlin. 2008. An unintended consequence of book-tax conformity: A loss of earnings informativeness. Journal of Accounting and Economics 46(2): 294-311. 
Hasan, I., S. Hoi, Q. Wu, and H. Zhang. 2016. Does Social Capital Matter in Corporate Decisions? Evidence from Corporate Tax Avoidance. Forthcoming at Journal of Accounting Research.

Khurana, I. K., and W. J. Moser. 2013. Institutional shareholders' investment horizons and tax avoidance. The Journal of the American Taxation Association 35(1): 111-134.

Kothari, S. P., A. J. Leone, and C. E. Wasley. 2005. Performance-matched discretionary accrual measures. Journal of Accounting and Economics 39(1): 163-197.

La Porta, R., F. Lopez-de-Silanes, A. Shleifer, and R. Vishny. 1998. Law and finance. Journal of Political Economy 106(6): 1113-1155.

La Porta, R., F. Lopez-de-Silanes, A. Shleifer, and R. Vishny. 2000. Investor protection and corporate governance. Journal of Financial Economics 58(1): 3-27.

Leuz, C., D. Nanda, and P. Wysocki. 2003. Earnings management and investor protection: An international comparison. Journal of Financial Economics 69(3): 505-527.

Li, Q., E. L. Maydew, R. H. Willis, and L. Xu. 2016. Political uncertainty and corporate tax avoidance: Evidence from national elections around the world. Working paper.

Luong, L. H., F. Moshirian, H. G. Nguyen, X. Tian, and B. Zhang. 2016. Do foreign institutional investors enhance firm innovation? Working paper.

Luttmer, E. F. P., and M. Singhal. 2014. Tax morale. Journal of Economic Perspectives 28(4): $149-168$.

McGuire, S. T., D. Wang, and R. J. Wilson. 2014. Dual class ownership and tax avoidance. The Accounting Review 89(4): 1487-1516.

Mills, L. F. 1998. Book-tax differences and Internal Revenue Service adjustments. Journal of Accounting Research 36(2): 343-356.

Palmer, D. A., P. D. Jennings, and X. Zhou. 1993. Late adoption of the multidivisional form by large US corporations: Institutional, political, and economic accounts. Administrative Science Quarterly 38(1): 100-131.

Rajan, R. G., and L. Zingales. 1998. Financial dependence and growth. American Economic Review 88(3): 559-586.

Richardson, G. 2006. Determinants of tax evasion: A cross-country investigation. International Accounting Auditing and Taxation 15(2): 150-169.

Richupan, S. 1984. Measuring tax evasion. Finance and Development 21(4): 38. 
Table 1

Descriptive Statistics

This table presents descriptive statistics on our sample of 47,749 firm-year observations for the period from 2000 to 2008. TaxAvoid is annual tax avoidance spread measured as a firm's home-country statutory tax rate minus cash effective tax rate. Totown is total institutional ownership. Forown is aggregate foreign institutional ownership. Forown_HighMorale (Forown_LowMorale) is aggregate ownership of foreign institutional investors whose home countries are classified as having high (low) tax morale. Forown_CommonLaw (Forown_CivilLaw) is aggregate ownership of foreign institutional investors whose home countries are classified as common-law (civil-law) countries. Forown_Long (Forown_Short) is aggregate ownership of long-term (short-term) foreign institutional investors. Domown is aggregate domestic institutional ownership. Domown_Long (Domown_Short) is aggregate ownership of long-term (short-term) domestic institutional investors. Assets measures a firm's book value of assets at the end of fiscal year. Leverage is book value of debts scaled by assets. ROA is operating income scaled by assets. Sales Growth is the growth rate of sales year to year. $R \& D$ is research and development expenditure scaled by lagged assets. Accrual is residual obtained from the discretionary accrual model (Kothari, Leone, and Wasley 2005). Tax Rate is a country's statutory tax rate. Foreign Operations is an indicator that equals 1 if a firm has nonzero foreign sales and 0 otherwise. Appendix A contains detailed definitions of the variables.

\begin{tabular}{|c|c|c|c|c|c|c|}
\hline Variable Name & $\mathrm{N}$ & Mean & Median & $\begin{array}{l}\text { Standard } \\
\text { Deviation }\end{array}$ & $\begin{array}{c}\text { 25th } \\
\text { Percentile }\end{array}$ & $\begin{array}{c}\text { 75th } \\
\text { Percentile }\end{array}$ \\
\hline TaxAvoid & 47,749 & 0.053 & 0.062 & 0.231 & -0.014 & 0.190 \\
\hline Totown & 47,749 & 0.094 & 0.051 & 0.115 & 0.012 & 0.133 \\
\hline Forown & 47,749 & 0.047 & 0.016 & 0.072 & 0.003 & 0.061 \\
\hline Forown_HighMorale & 47,749 & 0.030 & 0.009 & 0.050 & 0.001 & 0.037 \\
\hline Forown_LowMorale & 47,749 & 0.017 & 0.002 & 0.034 & 0.000 & 0.019 \\
\hline $\begin{array}{l}\text { Forown_CommonLa } \\
w\end{array}$ & $\begin{array}{c}47,74 \\
9\end{array}$ & 0.0359 & 0.0105 & 0.0591 & 0.0015 & 0.0456 \\
\hline Forown_CivilLaw & $\begin{array}{c}47,74 \\
9\end{array}$ & 0.0098 & 0.0007 & 0.0218 & 0.0000 & 0.0100 \\
\hline Forown_Long & 47,749 & 0.035 & 0.011 & 0.057 & 0.002 & 0.045 \\
\hline Forown_Short & 47,749 & 0.011 & 0.001 & 0.024 & 0.000 & 0.012 \\
\hline Domown & 47,749 & 0.048 & 0.014 & 0.084 & 0.000 & 0.056 \\
\hline Domown_Long & 47,749 & 0.030 & 0.004 & 0.060 & 0.000 & 0.031 \\
\hline Domown_Short & 47,749 & 0.018 & 0.002 & 0.047 & 0.000 & 0.018 \\
\hline Assets ( $\$$ in million) & 47,749 & $\begin{array}{c}2367.63 \\
0\end{array}$ & $\begin{array}{l}313.74 \\
\quad 7\end{array}$ & 10291.000 & 111.916 & 1033.740 \\
\hline Leverage & 47,749 & 0.202 & 0.183 & 0.165 & 0.052 & 0.316 \\
\hline$R O A$ & 47,749 & 0.061 & 0.046 & 0.055 & 0.023 & 0.083 \\
\hline Sales Growth & 47,749 & 0.171 & 0.093 & 0.380 & 0.009 & 0.230 \\
\hline$R \& D$ & 47,749 & 0.011 & 0.000 & 0.025 & 0.000 & 0.008 \\
\hline Accruals & 47,749 & 0.049 & 0.062 & 0.221 & -0.008 & 0.133 \\
\hline Tax Rate & 47,749 & 0.321 & 0.330 & 0.071 & 0.280 & 0.392 \\
\hline Foreign Operations & 47,749 & 0.477 & 0.000 & 0.499 & 0.000 & 1.000 \\
\hline MSCI Inclusion & 47,749 & 0.106 & 0.000 & 0.307 & 0.000 & 0.000 \\
\hline CivilLaw & 47,749 & 0.687 & 1.000 & 0.464 & 0.000 & 1.000 \\
\hline EconDevelop & 47,749 & 0.686 & 1.000 & 0.464 & 0.000 & 1.000 \\
\hline GovEffect & 47,749 & 1.246 & 1.425 & 0.643 & 1.053 & 1.719 \\
\hline Accountability & 47,749 & 0.768 & 0.951 & 0.743 & 0.513 & 1.309 \\
\hline RegQuality & 47,749 & 1.055 & 1.141 & 0.647 & 0.746 & 1.584 \\
\hline Anti-Corruption & 42,498 & 67.060 & 71.000 & 20.152 & 58.000 & 83.000 \\
\hline
\end{tabular}


Table 2

Summary Statistics by Country

This table presents tax avoidance and institutional ownership by country. TaxAvoid is average tax avoidance spread measured as a firm's home-country statutory tax rate minus cash effective tax rate at year $t$ for each country. Totown is average total institutional ownership in each country. Forown is average aggregate foreign institutional ownership in each country. Domown is average aggregate domestic institutional ownership in each country. Tax Morale Index is the percentage of the individuallevel tax morale scores in a given country, obtained from the World Values Survey (WVS).

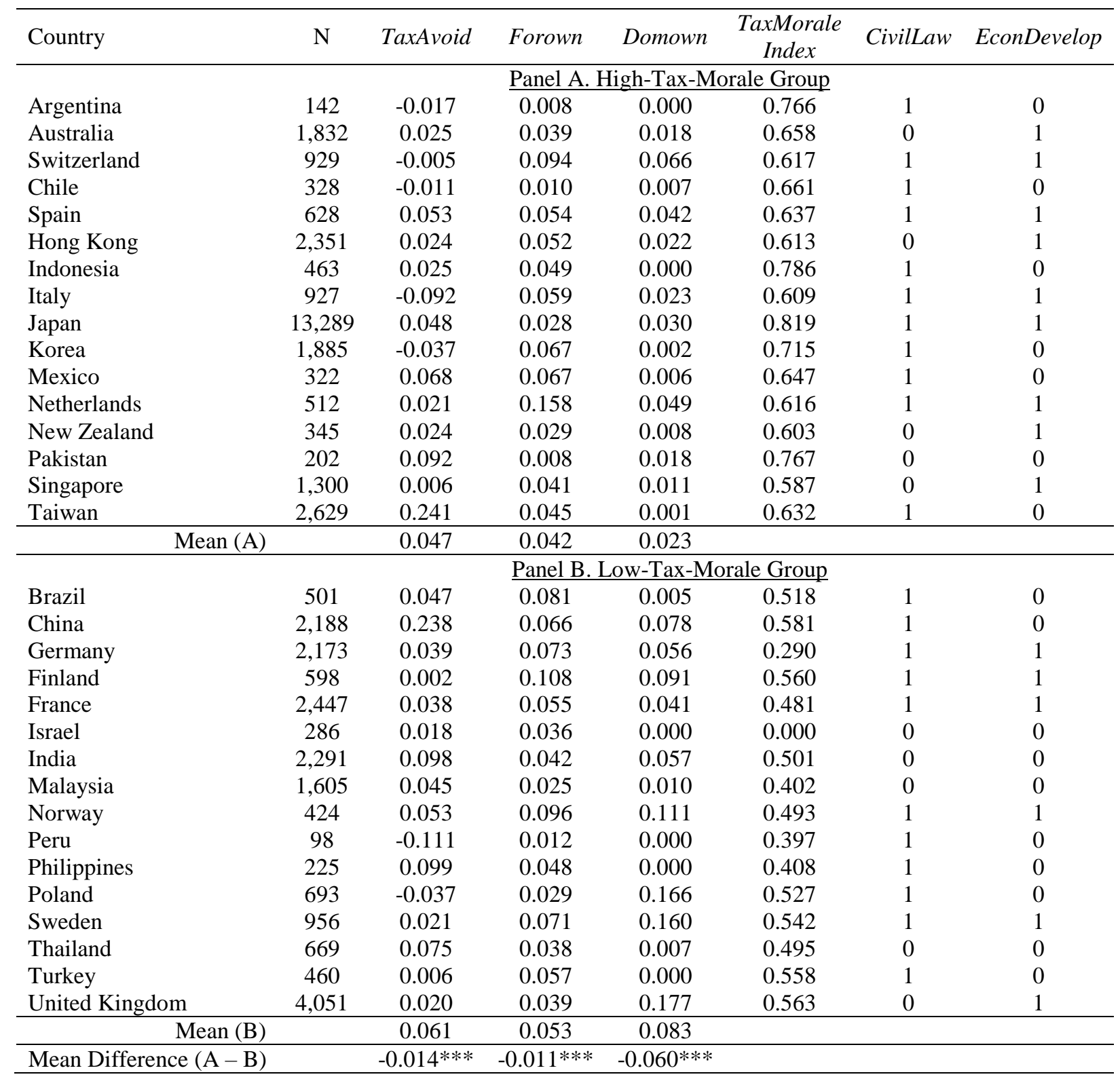


Table 3

Foreign Institutional Ownership and Tax Avoidance

This table presents results from OLS regressions in which the dependent variable is TaxAvoid, the annual tax avoidance spread measured as a firm's home-country statutory tax rate minus cash effective tax rate at year $t$. Totown is total institutional ownership. Domown is aggregate domestic institutional ownership. Forown is aggregate foreign institutional ownership. Appendix A provides detailed definitions of the control variables. Industry, country, and year dummies are included, but coefficients are omitted for brevity. Numbers in parentheses are $t$-statistics computed using standard errors that are clustered at the firm level. ***, **, and * indicate significance at the $1 \%, 5 \%$, and $10 \%$ levels, respectively.

Dependent variable: TaxAvoid

\begin{tabular}{|c|c|c|}
\hline \multirow[b]{2}{*}{ Totown } & \\
\hline & $\begin{array}{c}\frac{\text { Full Sample }}{-0.042 * * *} \\
(-3.23)\end{array}$ & Full Sample \\
\hline Forown & & $\begin{array}{c}-0.080 * * * \\
(-3.98)\end{array}$ \\
\hline Domown & & $\begin{array}{l}-0.007 \\
(-0.44)\end{array}$ \\
\hline $\operatorname{Ln}(\operatorname{Size})$ & $\begin{array}{c}0.006 * * * \\
(5.81)\end{array}$ & $\begin{array}{c}0.006 * * * \\
(6.21)\end{array}$ \\
\hline Leverage & $\begin{array}{c}0.064 * * * \\
(6.98)\end{array}$ & $\begin{array}{c}0.063 * * * \\
(6.86)\end{array}$ \\
\hline$R O A$ & $\begin{array}{c}0.796 * * * \\
(24.17)\end{array}$ & $\begin{array}{c}0.802 * * * \\
(24.27)\end{array}$ \\
\hline Sales Growth & $\begin{array}{c}0.023^{* * * *} \\
(6.48)\end{array}$ & $\begin{array}{c}0.023 * * * \\
(6.53)\end{array}$ \\
\hline$R \& D$ & $\begin{array}{l}0.060 \\
(1.06)\end{array}$ & $\begin{array}{l}0.066 \\
(1.15)\end{array}$ \\
\hline Accrual & $\begin{array}{l}-0.000 \\
(-0.06)\end{array}$ & $\begin{array}{l}-0.001 \\
(-0.17)\end{array}$ \\
\hline Tax Rate & $\begin{array}{c}0.576^{* * * *} \\
(7.73)\end{array}$ & $\begin{array}{c}0.594 * * * \\
(7.93)\end{array}$ \\
\hline Foreign Operations & $\begin{array}{l}0.002 \\
(0.64)\end{array}$ & $\begin{array}{l}0.002 \\
(0.61)\end{array}$ \\
\hline Constant & $\begin{array}{c}-0.339 * * * \\
(-8.87)\end{array}$ & $\begin{array}{c}-0.349 * * * \\
(-9.07)\end{array}$ \\
\hline Year FE & YES & YES \\
\hline Industry FE & YES & YES \\
\hline Country FE & YES & YES \\
\hline Observations & 47,749 & 47,749 \\
\hline Adjusted $\mathrm{R}^{2}$ & 0.131 & 0.131 \\
\hline
\end{tabular}


Table 4

Country Characteristics

This table presents results from OLS regressions in which the dependent variable is TaxAvoid, the annual tax avoidance spread measured as a firm's homecountry statutory tax rate minus cash effective tax rate at year $t$. CivilLaw is an indicator that equals 1 if a country's legal system is based on civil law and 0 if common law. GovEffect measures perceptions of the quality of public services as well as the quality of the civil services and the degree of its independence from political pressure. RegQuality measures perceptions of the government's ability to formulate and implement sound policies and regulations that permit and promote private sector development. Accountability measures perceptions of the extent to which a country's citizens can participate in selecting their government, as well as freedom of expression. EconDevelop is an indicator that equals 1 if a country is classified as a developed country and 0 otherwise. AntiCorruption measures perceptions of the extent to which public power is exercised for private gain. The natural logarithm of tax morale index ( $\ln ($ Tax Morale Index)) is obtained from the World Values Survey (WVS). Firm characteristics variables, industry and year dummies, and interaction terms between year and country are included, but coefficients are omitted for brevity. Numbers in parentheses are $t$-statistics computed using standard errors that are clustered at the firm level. $* * *, * *$, and $*$ indicate significance at the $1 \%, 5 \%$, and $10 \%$ levels, respectively.

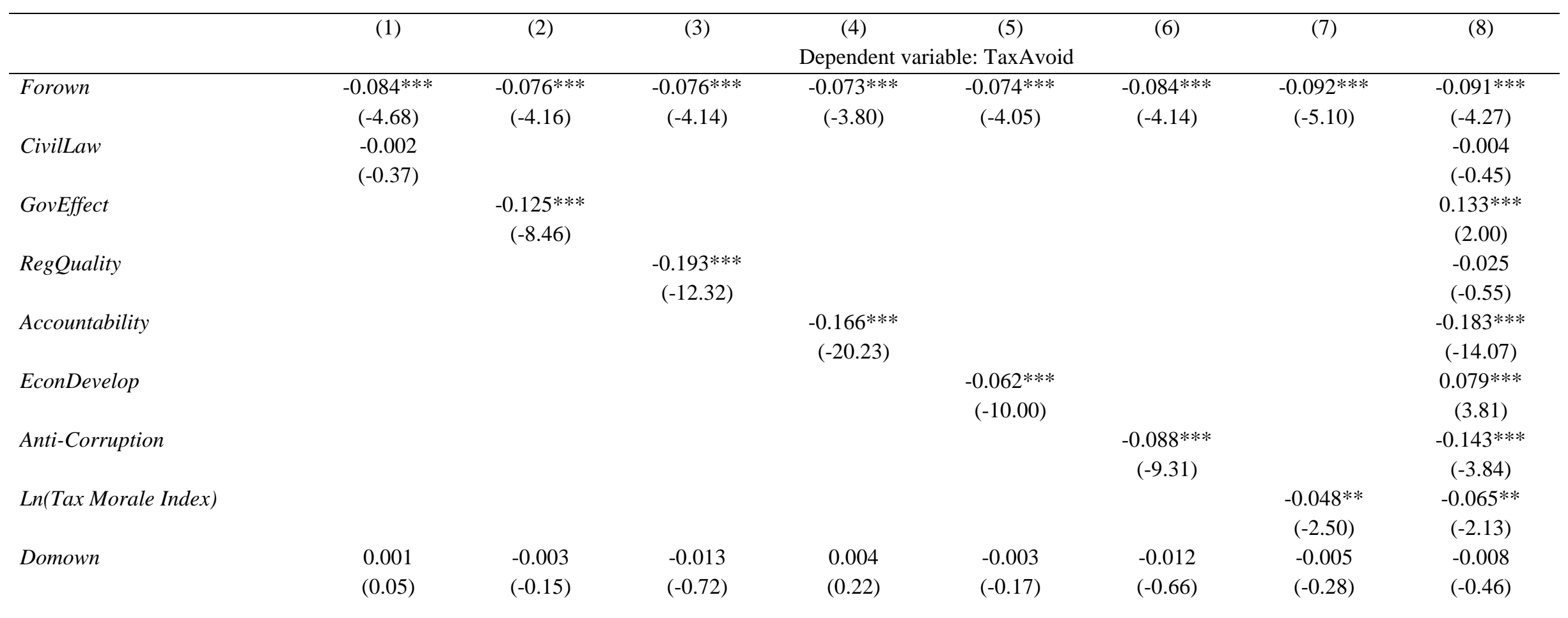




\begin{tabular}{|c|c|c|c|c|c|c|c|c|}
\hline Constant & $\begin{array}{c}-0.137 * * * \\
(-3.15)\end{array}$ & $\begin{array}{l}0.006 \\
(1.38)\end{array}$ & $\begin{array}{c}0.237 * * * \\
(4.83)\end{array}$ & $\begin{array}{c}0.170 * * * \\
(3.72)\end{array}$ & $\begin{array}{c}-0.089 * * \\
(-2.09)\end{array}$ & $\begin{array}{c}0.254 * * * \\
(4.30)\end{array}$ & $\begin{array}{c}-0.151 * * * \\
(-3.51)\end{array}$ & $\begin{array}{c}0.623 * * * \\
(6.13)\end{array}$ \\
\hline Controls & YES & YES & YES & YES & YES & YES & YES & YES \\
\hline Year FE & YES & YES & YES & YES & YES & YES & YES & YES \\
\hline Industry FE & YES & YES & YES & YES & YES & YES & YES & YES \\
\hline Country*Year FE & YES & YES & YES & YES & YES & YES & YES & YES \\
\hline Observations & 47,749 & 47,749 & 47,749 & 47,749 & 47,749 & 42,498 & 47,463 & 42,212 \\
\hline Adjusted $\mathrm{R}^{2}$ & 0.122 & 0.124 & 0.127 & 0.134 & 0.125 & 0.0906 & 0.123 & 0.101 \\
\hline
\end{tabular}


Table 5

Two-Stage Least Squares (2SLS) Model

To address potential endogenous bias, we use 2SLS model with MSCI Inclusion as the instrumental variable for foreign institutional ownership. MSCI Inclusion equals 1 if a given firm is included in MSCI in a given year $t$ and 0 otherwise. We then regress tax avoidance on predicted foreign institutional ownership (Pred_Forown) from first-stage regression. Numbers in parentheses are $t$-statistics computed using standard errors that are clustered at the firm level. ***,**, and * indicate significance at the $1 \%$, $5 \%$, and $10 \%$ levels, respectively.

\begin{tabular}{|c|c|c|}
\hline Dependent variable & $\begin{array}{c}(1) \\
\text { Forown }\end{array}$ & $\begin{array}{c}(2) \\
\text { TaxAvoid }\end{array}$ \\
\hline & $\underline{1 \text { st }^{\text {Stage }}}$ & $\underline{2^{\text {nd }} \text { Stage }}$ \\
\hline MSCI Inclusion & $\begin{array}{c}0.044 * * * \\
(17.01)\end{array}$ & \\
\hline Pred_Forown & & $\begin{array}{c}-0.241 * * * \\
(-2.60)\end{array}$ \\
\hline Domown & $\begin{array}{l}0.012 \\
(1.61)\end{array}$ & $\begin{array}{l}-0.006 \\
(-0.36)\end{array}$ \\
\hline $\operatorname{Ln}(\operatorname{Size})$ & $\begin{array}{c}0.014 * * * \\
(31.74)\end{array}$ & $\begin{array}{c}0.009^{* * *} \\
(4.61)\end{array}$ \\
\hline Leverage & $\begin{array}{c}-0.020 * * * \\
(-5.55)\end{array}$ & $\begin{array}{c}0.059 * * * \\
(6.32)\end{array}$ \\
\hline$R O A$ & $\begin{array}{c}0.142 * * * \\
(12.73)\end{array}$ & $\begin{array}{c}0.830 * * * \\
(22.29)\end{array}$ \\
\hline Sales Growth & $\begin{array}{c}0.006^{* * * *} \\
(7.09)\end{array}$ & $\begin{array}{c}0.024 * * * \\
(6.68)\end{array}$ \\
\hline$R \& D$ & $\begin{array}{c}0.170^{* * * *} \\
(6.53)\end{array}$ & $\begin{array}{l}0.096 \\
(1.60)\end{array}$ \\
\hline Accrual & $\begin{array}{c}0.008 * * * \\
(4.58)\end{array}$ & $\begin{array}{l}-0.001 \\
(-0.12)\end{array}$ \\
\hline Tax Rate & $\begin{array}{c}0.048^{*} \\
(1.92)\end{array}$ & $\begin{array}{c}0.604 * * * \\
(8.05)\end{array}$ \\
\hline Foreign Operations & $\begin{array}{l}0.002 \\
(1.16)\end{array}$ & $\begin{array}{l}0.003 \\
(0.78)\end{array}$ \\
\hline Constant & $\begin{array}{c}-0.133 * * * \\
(-11.13)\end{array}$ & $\begin{array}{c}-0.370 * * * \\
(-8.69)\end{array}$ \\
\hline Year FE & YES & YES \\
\hline Industry FE & YES & YES \\
\hline Country FE & YES & YES \\
\hline Observations & 47,749 & 47,749 \\
\hline Adjusted $\mathrm{R}^{2}$ & 0.315 & 0.130 \\
\hline
\end{tabular}


Table 6

Qualified Foreign Institutional Investors Reform in China and Tax Avoidance

This table presents results of the difference-in-differences regression that examines the effect of China's Qualified Foreign Institutional Investors (QFII) reform in 2002 on tax avoidance. It provides results from four pooled OLS regressions. Post-Reform is an indicator that equals 1 (0) for years after (before) the 2002 reform. China is an indicator that equals 1 if the investee firms are located in China and 0 otherwise. China*Reform captures the incremental post-reform effect in China. Numbers in parentheses are $t$-statistics computed using standard errors that are clustered at the firm level. ***,**, and $*$ indicate significance at the $1 \%, 5 \%$, and $10 \%$ levels, respectively.

\begin{tabular}{|c|c|c|c|c|}
\hline & \multicolumn{4}{|c|}{ Dependent variable: TaxAvoid } \\
\hline & Low-Tax-Morale & Emerging & Civil-Law & $\frac{\text { Low-Tax-Morale, Emerging, }}{\text { and Civil-Law }}$ \\
\hline Post-Reform & $\begin{array}{c}0.031 * * * \\
(3.59)\end{array}$ & $\begin{array}{c}0.027^{*} \\
(1.92)\end{array}$ & $\begin{array}{c}0.038^{* * *} \\
(5.21)\end{array}$ & $\begin{array}{c}0.069^{*} \\
(1.83)\end{array}$ \\
\hline China & $\begin{array}{c}0.186 * * * \\
(4.97)\end{array}$ & $\begin{array}{l}0.336 * * * \\
(7.46)\end{array}$ & $\begin{array}{c}0.331 * * * \\
(6.97)\end{array}$ & $\begin{array}{c}0.127 * * * \\
(2.79)\end{array}$ \\
\hline China* Post-Reform & $\begin{array}{c}-0.040^{*} \\
(-1.71)\end{array}$ & $\begin{array}{c}-0.053 * * \\
(-2.12)\end{array}$ & $\begin{array}{c}-0.043^{*} \\
(-1.86)\end{array}$ & $\begin{array}{c}-0.067 * \\
(-1.83)\end{array}$ \\
\hline $\operatorname{Ln}(\operatorname{Size})$ & $\begin{array}{l}0.007 * * \\
(2.53)\end{array}$ & $\begin{array}{l}-0.001 \\
(-0.14)\end{array}$ & $\begin{array}{l}0.008 * * * \\
(3.70)\end{array}$ & $\begin{array}{l}-0.003 \\
(-0.24)\end{array}$ \\
\hline Leverage & $\begin{array}{c}0.069 * * \\
(2.28)\end{array}$ & $\begin{array}{c}0.124 * * * \\
(3.10)\end{array}$ & $\begin{array}{l}0.028 \\
(1.33)\end{array}$ & $\begin{array}{l}0.105 \\
(1.18)\end{array}$ \\
\hline$R O A$ & $\begin{array}{l}0.758 * * * \\
(7.66)\end{array}$ & $\begin{array}{c}1.004 * * * \\
(6.86)\end{array}$ & $\begin{array}{c}0.687 * * * \\
(7.15)\end{array}$ & $\begin{array}{c}0.499^{* *} \\
(2.12)\end{array}$ \\
\hline Sales Growth & $\begin{array}{l}0.014 \\
(1.29)\end{array}$ & $\begin{array}{l}-0.001 \\
(-0.07)\end{array}$ & $\begin{array}{l}0.013 \\
(1.42)\end{array}$ & $\begin{array}{l}-0.008 \\
(-0.36)\end{array}$ \\
\hline$R \& D$ & $\begin{array}{l}-0.174 \\
(-1.45)\end{array}$ & $\begin{array}{c}-0.611 * * \\
(-1.98)\end{array}$ & $\begin{array}{l}-0.160 \\
(-1.22)\end{array}$ & $\begin{array}{l}-0.009 \\
(-0.01)\end{array}$ \\
\hline Accrual & $\begin{array}{c}-0.045^{* *} \\
(-2.36)\end{array}$ & $\begin{array}{l}-0.011 \\
(-0.45)\end{array}$ & $\begin{array}{l}-0.014 \\
(-0.76)\end{array}$ & $\begin{array}{l}-0.002 \\
(-0.06)\end{array}$ \\
\hline Tax Rate & $\begin{array}{c}0.747 * * * \\
(3.36)\end{array}$ & $\begin{array}{l}0.514 \\
(1.34)\end{array}$ & $\begin{array}{c}0.830 * * * \\
(3.82)\end{array}$ & $\begin{array}{l}0.306 \\
(0.68)\end{array}$ \\
\hline Foreign Operations & $\begin{array}{l}-0.015 \\
(-1.37)\end{array}$ & $\begin{array}{l}-0.010 \\
(-0.70)\end{array}$ & $\begin{array}{l}0.002 \\
(0.26)\end{array}$ & $\begin{array}{l}-0.026 \\
(-0.70)\end{array}$ \\
\hline Constant & $\begin{array}{c}-0.329 * * * \\
(-3.76)\end{array}$ & $\begin{array}{c}-0.365^{* *} \\
(-2.57)\end{array}$ & $\begin{array}{c}-0.502 * * * \\
(-5.64)\end{array}$ & $\begin{array}{l}-0.088 \\
(-0.51)\end{array}$ \\
\hline Year FE & YES & YES & YES & YES \\
\hline Industry FE & YES & YES & YES & YES \\
\hline Country FE & YES & YES & YES & YES \\
\hline Observations & 3,891 & 2,105 & 7,338 & 431 \\
\hline Adjusted $\mathrm{R}^{2}$ & 0.102 & 0.182 & 0.0939 & 0.126 \\
\hline
\end{tabular}


Table 7

The Effect of Significant Changes in Institutional Ownership on Tax Avoidance

This table presents results of the difference-in-differences regression that examines the effect of a significant change in foreign (domestic) institutional ownership on tax avoidance. The dependent variable is TaxAvoid, the annual tax avoidance spread measured as a firm's home-country statutory tax rate minus the cash effective tax rate at year $t$. IncFor (IncDom) is an indicator that equals 1 if foreign (domestic) institutional ownership increases by at least one standard deviation and 0 otherwise. Post is an indicator that equals 1 for years after foreign (domestic) institutional ownership increases by at least one standard deviation and 0 otherwise. Firm characteristics variables, as well as industry, country, and year dummies, are included, but coefficients are omitted for brevity. Numbers in parentheses are $t$ statistics computed using standard errors that are clustered at the firm level. ***, **, and * indicate significance at the $1 \%, 5 \%$, and $10 \%$ levels, respectively.

\begin{tabular}{lcccc}
\hline & $(1)$ & $(2)$ & $(3)$ & $(4)$ \\
\hline Post & -0.007 & $-0.023^{* * *}$ & 0.003 & -0.009 \\
IncFor & $(-0.85)$ & $(-2.34)$ & $(0.39)$ & $(-0.93)$ \\
& $0.028^{* * *}$ & & 0.010 & \\
Post* IncFor & $(3.43)$ & & $(1.32)$ & \\
& $-0.025^{* *}$ & & $-0.019^{* *}$ & \\
IncDom & $(-2.51)$ & & $(-1.97)$ & \\
& & & & 0.011 \\
Post*IncDom & & $(3.73)$ & & $(-0.93)$ \\
& & $-0.034^{* * *}$ & & -0.002 \\
Constant & $(-2.61)$ & & $(-0.18)$ \\
& $-0.379^{* * *}$ & $0.040^{* * *}$ & $-0.379^{* * *}$ & $-0.532^{* * *}$ \\
Controls & $(-5.83)$ & $(5.42)$ & $(-5.83)$ & $(-5.66)$ \\
Year FE & NO & NO & YES & YES \\
Industry FE & NO & NO & YES & YES \\
Country FE & NO & NO & YES & YES \\
\hline Observations & NO & NO & YES & YES \\
Adjusted $\mathrm{R}^{2}$ & 7,207 & 5,849 & 7,207 & 5,849 \\
\hline
\end{tabular}


Table 8

Mechanism 1: Tax Morale and Tax Avoidance

This table presents the results of our first mechanism, tax morale. The dependent variable is TaxAvoid, the annual tax avoidance spread measured as a firm's home-country statutory tax rate minus the cash effective tax rate at year $t$. Forown_HighMorale (Forown_LowMorale) is aggregate ownership of foreign institutional investors whose home countries are classified as high-(low-)tax-morale countries. We further bisect the full sample into two subsamples: investee firms in countries with low tax morale and investee firms in countries with high tax morale, and we repeat the test. Firm characteristics variables, as well as industry, country, and year dummies, are included, but coefficients are omitted for brevity. Numbers in parentheses are $t$-statistics computed using standard errors that are clustered at the firm level. $* * *, * *$, and $*$ indicate significance at the $1 \%, 5 \%$, and $10 \%$ levels, respectively.

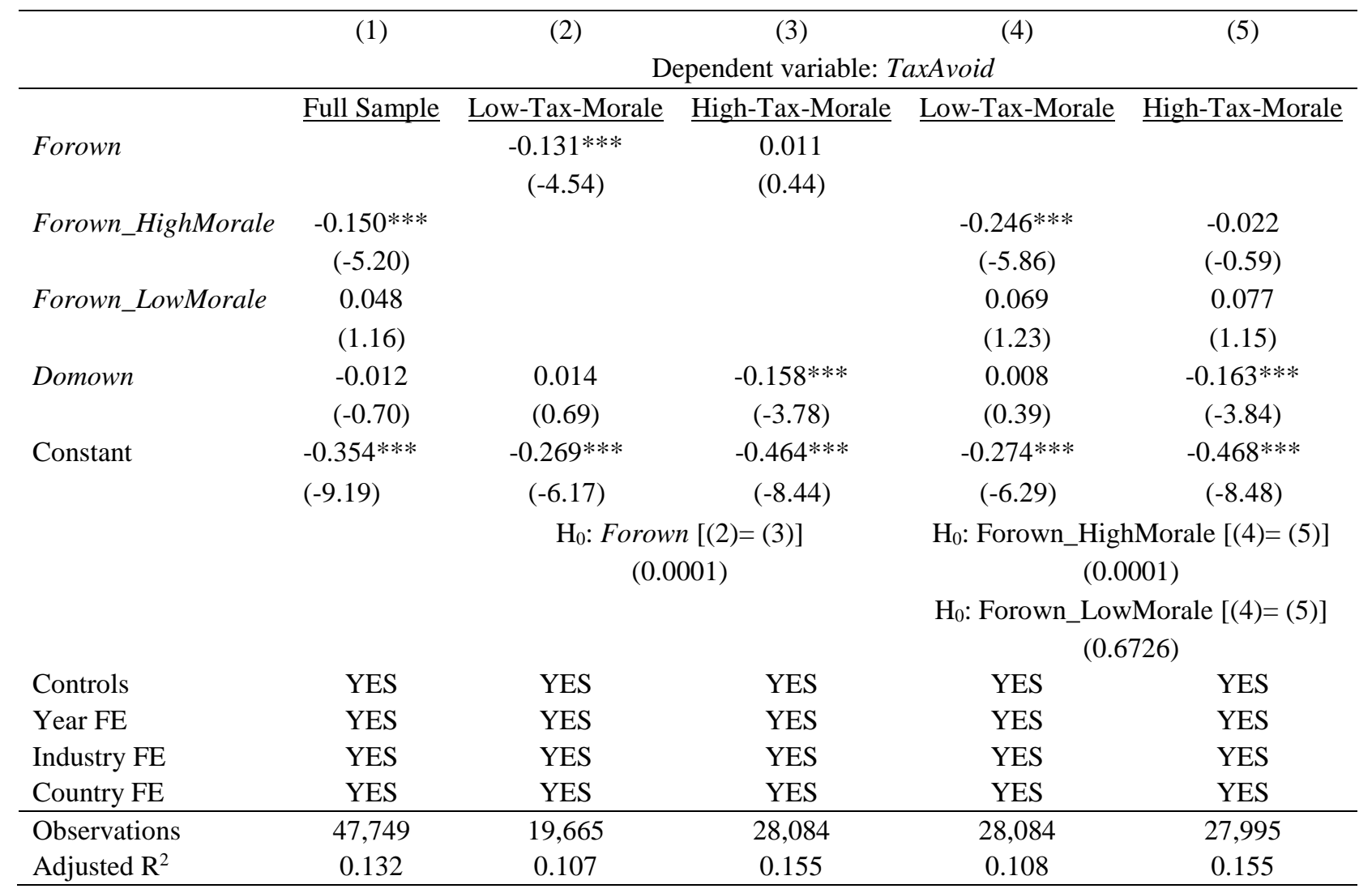


Table 9

Mechanism 2: Shareholder Protection and Tax Avoidance

This table presents results of our second mechanism, shareholder protection. The dependent variable is TaxAvoid, the annual tax avoidance spread measured as a firm's home-country statutory tax rate minus its cash effective tax rate at year $t$. Forown_CommonLaw (Forown_CivilLaw) is aggregate ownership of foreign institutional investors whose home countries are classified as common-law (civil-law) countries. We further bisect the full sample into two subsamples: investee firms in civil-law countries and investee firms in common-law countries, and we repeat the test. Firm characteristics variables, as well as industry, country, and year dummies, are included, but coefficients are omitted for brevity. Numbers in parentheses are $t$-statistics computed using standard errors that are clustered at the firm level. $* * *, * *$, and $*$ indicate significance at the $1 \%, 5 \%$, and $10 \%$ levels, respectively.

\begin{tabular}{|c|c|c|c|c|c|}
\hline & (1) & (2) & (3) & (4) & (5) \\
\hline & \multicolumn{5}{|c|}{ Dependent variable: TaxAvoid } \\
\hline Forown & Full Sample & $\frac{\text { Civil Law }}{-0.116^{* * *}}$ & $\begin{array}{c}\text { Common Law } \\
0.040 \\
(1.08)\end{array}$ & Civil Law & Common Law \\
\hline Forown_CommonLaw & $\begin{array}{c}-0.113 * * * \\
(-4.68)\end{array}$ & & & $\begin{array}{c}-0.163 * * * * \\
(-5.82)\end{array}$ & $\begin{array}{l}0.037 \\
(0.80)\end{array}$ \\
\hline Forown_CivilLaw & $\begin{array}{l}0.071 \\
(1.06)\end{array}$ & & & $\begin{array}{l}0.085 \\
(1.13)\end{array}$ & $\begin{array}{l}0.061 \\
(0.43)\end{array}$ \\
\hline Domown & $\begin{array}{l}-0.009 \\
(-0.55)\end{array}$ & $\begin{array}{l}0.026 \\
(1.50)\end{array}$ & $\begin{array}{c}-0.074 * * \\
(-2.12)\end{array}$ & $\begin{array}{l}0.023 \\
(1.31)\end{array}$ & $\begin{array}{c}-0.074 * * \\
(-2.12)\end{array}$ \\
\hline \multirow[t]{2}{*}{ Constant } & $\begin{array}{c}-0.351 * * * \\
(-9.12)\end{array}$ & $\begin{array}{c}-0.367 * * * \\
(-8.86)\end{array}$ & $\begin{array}{c}-0.236 * * * \\
(-3.81)\end{array}$ & $\begin{array}{c}-0.370 * * * \\
(-8.94)\end{array}$ & $\begin{array}{c}-0.236 * * * \\
(-3.79)\end{array}$ \\
\hline & & \multicolumn{2}{|c|}{$\begin{array}{c}\mathrm{H}_{0}: \text { Forown }[(2)=(3)] \\
(0.0004)\end{array}$} & \multicolumn{2}{|c|}{$\begin{array}{c}\mathrm{H}_{0} \text { : Forown_CommonLaw }[(4)=(5)] \\
\begin{array}{c}(0.0002) \\
\mathrm{H}_{0} \text { : Forown_CivilLaw }[(4)=(5)] \\
(0.8837)\end{array}\end{array}$} \\
\hline Controls & & YES & YES & YES & YES \\
\hline Year FE & & YES & YES & YES & YES \\
\hline Industry FE & & YES & YES & YES & YES \\
\hline Country FE & & YES & YES & YES & YES \\
\hline Observations & 47,749 & 32,817 & 14,932 & 32,817 & 14,932 \\
\hline Adjusted $\mathrm{R}^{2}$ & 0.132 & 0.159 & 0.0774 & 0.159 & 0.0773 \\
\hline
\end{tabular}


Table 10

Corruption and Tax Avoidance

This table presents regression result of corruption and tax avoidance. The dependent variable is TaxAvoid, the annual tax avoidance spread measured as a firm's home-country statutory tax rate minus the cash effective tax rate at year $t$.Forown_HighCrpt_HighMoral (Forown_LowCrpt_HighMoral) is aggregate ownership of foreign institutional investors from high-corruption and high-tax-morale (lowcorruption and high-tax-morale) countries. Forown_HighCrpt_LowMoral (Forown_LowCrpt_LowMoral) is aggregate ownership of foreign institutional investors from highcorruption and low-tax-morale (low-corruption and low-tax-morale) countries. Domown is aggregate ownership of domestic institutional investors. Firm characteristics variables, as well as industry, country, and year dummies are included, but coefficients are omitted for brevity. Numbers in parentheses are $t$ statistics computed using standard errors that are clustered at the firm level. ***,**, and * indicate significance at the $1 \%, 5 \%$, and $10 \%$ levels, respectively.

(1)

Dependent variable: TaxAvoid

Forown_HighCrpt_HighMoral

Forown_LowCrpt_HighMoral

Forown_LowCrpt_LowMoral

Forown_HighCrpt_LowMoral

Domown

Constant

Controls

Year FE

Industry FE

Country FE

Observations

Adjusted R ${ }^{2}$

\section{Full Sample}

$-0.111 * * *$

$-0.200 * * *$

$0.091^{* *}$

$-0.285$

$-0.014$

$-0.354 * * *$

YES

YES

YES

YES

47,749

0.132 
Table 11

Investment Horizon and Tax Avoidance

This table presents regression result of investment horizon and tax avoidance. The dependent variable is TaxAvoid, the annual tax avoidance spread measured as a firm's home-country statutory tax rate minus the cash effective tax rate at year t. Forown_Long (Forown_Short) is aggregate ownership of long-term (short-term) foreign institutional investors. Domown_Long (Domown_Short) is aggregate ownership of long-term (short-term) domestic institutional investors. Firm characteristics variables, as well as industry, country, and year dummies are included, but coefficients are omitted for brevity. Numbers in parentheses are $t$-statistics computed using standard errors that are clustered at the firm level. ***,**, and * indicate significance at the $1 \%, 5 \%$, and $10 \%$ levels, respectively.

(1)

Dependent variable: TaxAvoid

Forown_Long

Full Sample

$-0.094 * * *$

Forown_Short

Forown_Short

$-0.021$

Domown_Long

Domown_Short

$-0.067 * *$

Domown_Short

$0.059 * *$

Constant

$-0.362 * * *$

$(-9.28)$

Controls

YES

Year FE

YES

Industry FE YES

Country FE

YES

Observations

47,749

Adjusted R ${ }^{2}$

0.132 
Table 12

Other Additional Analyses

This table presents results of four other additional analyses. Panel A uses a country's economic development as an alternative proxy for tax morale. Panel B investigates tax aggressiveness instead of tax avoidance. Panel $\mathrm{C}$ uses sample that only retains members of the Group of Twenty (G20). Panel D further splits FIIs (e.g., Forown_HighMorale) into US FIIs (e.g., Forown_HighMorale_US $S_{t}$ ) and nonUS FIIs (e.g., Forown_HighMorale_Others). All analyses include control variables (firm characteristics as well as year, industry, and country dummies) used in the baseline model but omitted for brevity. Numbers in parentheses are $t$-statistics computed using standard errors that are clustered at the firm level. ***,**, and * indicate significance at the $1 \%, 5 \%$, and $10 \%$ levels, respectively.

Panel A. Alternative Tax Morale: Economic Development

\begin{tabular}{|c|c|c|c|c|c|c|}
\hline & (1) & (2) & (3) & (4) & (5) & (6) \\
\hline & \multicolumn{6}{|c|}{ Dependent variable: TaxAvoid } \\
\hline Totown & $\begin{array}{c}\text { Emerging } \\
-0.074 * * * \\
(-3.94)\end{array}$ & 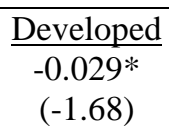 & Emerging & Developed & Emerging & Developed \\
\hline Domown & & & $\begin{array}{l}0.028 \\
(1.52)\end{array}$ & $\begin{array}{c}-0.054 * * \\
(-2.07)\end{array}$ & $\begin{array}{l}0.028 \\
(1.53)\end{array}$ & $\begin{array}{c}-0.054 * * \\
(-2.07)\end{array}$ \\
\hline Forown & & & $\begin{array}{c}-0.172 * * * \\
(-5.82)\end{array}$ & $\begin{array}{l}-0.003 \\
(-0.13)\end{array}$ & & \\
\hline Forown_Developed & & & & & $\begin{array}{c}-0.173 * * * \\
(-5.80)\end{array}$ & $\begin{array}{l}-0.002 \\
(-0.10)\end{array}$ \\
\hline Forown_Emerging & & & & & $\begin{array}{l}0.018 \\
(0.06)\end{array}$ & $\begin{array}{l}-0.070 \\
(-0.29)\end{array}$ \\
\hline Constant & $\begin{array}{c}-0.228 * * * \\
(-5.16)\end{array}$ & $\begin{array}{c}-0.344 * * * \\
(-9.05)\end{array}$ & $\begin{array}{c}-0.288 * * * \\
(-6.36)\end{array}$ & $\begin{array}{c}-0.346 * * * \\
(-9.08)\end{array}$ & $\begin{array}{c}-0.289 * * * \\
(-6.36)\end{array}$ & $\begin{array}{c}-0.346 * * * \\
(-9.07)\end{array}$ \\
\hline Observations & 15,502 & 35,034 & 15,502 & 35,034 & 15,502 & 35,034 \\
\hline Adjusted R² & 0.235 & 0.0592 & 0.237 & 0.0593 & 0.237 & 0.0593 \\
\hline
\end{tabular}

Panel B. Alternative Tax Avoidance Measure: Tax Aggressiveness

\begin{tabular}{|c|c|c|c|c|}
\hline & (1) & $(2)$ & (3) & (4) \\
\hline & & Dependent vari & TaxAggressive & \\
\hline & Full Sample & Full Sample & Full Sample & Full Sample \\
\hline Totown & $-0.685^{* * *}$ & & & \\
\hline & & & & \\
\hline Domown & & $-0.944 * * *$ & $-0.951 * * *$ & $-0.944 * * *$ \\
\hline & & $(-7.37)$ & $(-7.42)$ & $(-7.36)$ \\
\hline Forown & & $-0.414 * * *$ & & \\
\hline & & $(-2.89)$ & & \\
\hline Forown_HighMorale & & & $-0.543 * *$ & \\
\hline & & & $(-2.53)$ & \\
\hline Forown_LowMorale & & & -0.191 & \\
\hline & & & $(-0.65)$ & \\
\hline Forown_CommonLaw & & & & $-0.439 * *$ \\
\hline & & & & $(-2.40)$ \\
\hline Forown_CivilLaw & & & & -0.404 \\
\hline & & & & $(-0.97)$ \\
\hline Constant & $-1.602 * * *$ & $-1.559 * * *$ & $-1.566 * * *$ & $-1.561 * * *$ \\
\hline & $(-6.26)$ & $(-6.08)$ & $(-6.11)$ & $(-6.09)$ \\
\hline Observations & 47,724 & 47,724 & 47,724 & 47,724 \\
\hline Pseudo R ${ }^{2}$ & 0.0443 & 0.0445 & 0.0445 & 0.0297 \\
\hline
\end{tabular}


Panel C. G20 Countries Only

\section{(1)}

(2)

Dependent

\begin{tabular}{|c|c|c|c|c|}
\hline \multirow[b]{2}{*}{ Totown } & \multirow[b]{2}{*}{$\begin{array}{c}\text { Full Sample } \\
-0.046^{* * * *} \\
(-3.07)\end{array}$} & & \multirow[b]{2}{*}{ Full Sample } \\
\hline & & Full Sample & $\underline{\text { Full Sample }}$ & \\
\hline Domown & & $\begin{array}{l}-0.010 \\
(-0.52)\end{array}$ & $\begin{array}{l}-0.016 \\
(-0.89)\end{array}$ & $\begin{array}{l}-0.012 \\
(-0.67)\end{array}$ \\
\hline Forown & & $\begin{array}{c}-0.094 * * * \\
(-3.90)\end{array}$ & & \\
\hline Forown_HighMorale & & & $\begin{array}{c}-0.207 * * * \\
(-6.06)\end{array}$ & \\
\hline Forown_LowMorale & & & $\begin{array}{c}0.112 * * \\
(2.35)\end{array}$ & \\
\hline Forown_CommonLaw & & & & $\begin{array}{c}-0.145 * * * \\
(-4.97)\end{array}$ \\
\hline Forown_CivilLaw & & & & $\begin{array}{c}0.138^{*} \\
(1.93)\end{array}$ \\
\hline Constant & $\begin{array}{c}-0.363 * * * \\
(-8.64)\end{array}$ & $\begin{array}{c}-0.375 * * * \\
(-8.85)\end{array}$ & $\begin{array}{c}-0.382 * * * \\
(-9.03)\end{array}$ & $\begin{array}{c}-0.377 * * * \\
(-8.90)\end{array}$ \\
\hline Observations & 36,358 & 36,358 & 36,358 & 36,358 \\
\hline Pseudo $\mathrm{R}^{2}$ & 0.0942 & 0.0944 & 0.0947 & 0.0947 \\
\hline
\end{tabular}

Panel D. US vs. Non-US Institutional Investors

(1)

(2)

Dependent variable: TaxAvoid

\begin{tabular}{lcc}
\hline & Full Sample & Full Sample \\
\cline { 2 - 3 } Domown & -0.013 & -0.009 \\
& $(-0.77)$ & $(-0.55)$ \\
Forown_HighMorale_US & $-0.079^{*}$ & \\
& $(-1.92)$ & \\
Forown_HighMorale_Others & $-0.253^{* * *}$ & \\
& $(-5.07)$ & \\
Forown_LowMorale & 0.039 & $-0.068^{*}$ \\
& $(0.92)$ & $(-1.67)$ \\
Forown_CommonLaw_US & & $-0.157^{* * * *}$ \\
& & $(-4.03)$ \\
Forown_CommonLaw_Others & & 0.074 \\
Forown_CivilLaw & & $(1.09)$ \\
Constant & & $-0.350^{* * *}$ \\
& $-0.354^{* * *}$ & $(-9.09)$ \\
\hline Observations & $(-9.18)$ & 47,749 \\
Adjusted R & 47,749 & 0.132 \\
\hline
\end{tabular}


Appendix A

Definitions of Variables

\begin{tabular}{|c|c|}
\hline Variable Name & Description and Sources \\
\hline TaxAvoid & $\begin{array}{l}\text { Annual tax avoidance spread measured as a firm's home-country statutory tax rate less } \\
\text { cash effective tax rate. Cash effective tax rate = (Pretax earnings - Current cash tax } \\
\text { paid)/ Pretax earnings. If the current cash tax paid is missing, we replace it with total tax } \\
\text { expense less current deferred tax (Atwood et al. 2012). A country's statutory tax rate is } \\
\text { collected from the OECD and KPMG LLP websites. [Source: Global Compustat] }\end{array}$ \\
\hline Totown & Total institutional ownership for firm $i$ at year $t$. [Source: FactSet/LionShares] \\
\hline Forown & $\begin{array}{l}\text { Aggregate ownership of foreign institutional investors. An institutional investor is } \\
\text { classified as foreign when its headquarter is located in a different country from that of } \\
\text { its investee firm. [Source: FactSet/LionShares] }\end{array}$ \\
\hline Domown & Aggregate ownership of domestic institutional investors. [Source: FactSet/LionShares] \\
\hline $\begin{array}{l}\text { Forown_HighMorale } \\
\text { (Forown_LowMorale) }\end{array}$ & $\begin{array}{l}\text { Aggregate ownership of foreign institutional investors whose home countries are } \\
\text { classified as high- (low-)-tax-morale countries. [Source: FactSet/LionShares] High } \\
\text { (low) tax morale of a country is defined by that country's tax morale score being greater } \\
\text { (lower) than the median value. The tax morale index is constructed from the World } \\
\text { Values Survey (WVS). Data are available at the webpage via } \\
\text { http://www.worldvaluessurvey.org/WVSContents.jsp }\end{array}$ \\
\hline $\begin{array}{l}\text { Forown_CommonLaw } \\
\text { (Forown_CivilLaw) }\end{array}$ & $\begin{array}{l}\text { Aggregate ownership of foreign institutional investors whose home countries are } \\
\text { classified as common-law (civil-law) countries. [Source: FactSet/LionShares] }\end{array}$ \\
\hline $\begin{array}{l}\text { Forown_Long } \\
\text { (Forown_Short) }\end{array}$ & $\begin{array}{l}\text { Aggregate ownership of long-term (short-term) foreign institutional investors. Long- } \\
\text { term and short-term investment horizon are based on an institutional investor's turnover } \\
\text { rate. If an institutional investor's turnover rate is lower (higher) than its median value, it } \\
\text { is classified as long-term (short-term) institutional investors. [Source: } \\
\text { FactSet/LionShares] }\end{array}$ \\
\hline $\begin{array}{l}\text { Domown_Long(Domown } \\
\text { _Short) }\end{array}$ & $\begin{array}{l}\text { Aggregate ownership of long-term (short-term) domestic institutional investors } \\
\text { [Source: FactSet/LionShares] }\end{array}$ \\
\hline Tax Rate & Statutory tax rate for a country $j$ at year $t$. [Source: the OECD, KPMG LLP websites] \\
\hline Assets & Book value of assets (in US\$ million) at the end of year $t$. [Source: Global Compustat] \\
\hline Leverage & Book value of debts scaled by assets ((dlcc + dlt $) /$ at $).$ [Source: Global Compustat] \\
\hline ROA & Operating income scaled by assets (EBIT/at). [Source: Global Compustat] \\
\hline Sales Growth & Annual sales' growth rate $\left(\left(\mathrm{Sale}_{t} / \mathrm{Sale}_{t-1}\right)-1\right)$. [Source: Global Compustat] \\
\hline$R \& D$ & Research and development expenditure scaled by assets. [Source: Global Compustat] \\
\hline Accrual & $\begin{array}{l}\text { Discretionary accruals measured as residuals from the discretionary accrual model } \\
\text { (Kothari et al. 2005). [Source: Global Compustat] }\end{array}$ \\
\hline Foreign Operations & $\begin{array}{l}\text { An indicator that equals } 1 \text { if a firm has nonzero foreign sales and } 0 \text { otherwise. [Source: } \\
\text { WorldScope] }\end{array}$ \\
\hline MSCI Inclusion & $\begin{array}{l}\text { An indicator that equals } 1 \text { if a firm's stock is included in the MSCI index in a given year } \\
t \text {, and } 0 \text { otherwise. http://www.msci.com/products/indexes }\end{array}$ \\
\hline Accountability & $\begin{array}{l}\text { Reflects perceptions of the extent to which a country's citizens are able to participate in } \\
\text { selecting their government, as well as freedom of expression, freedom of association, } \\
\text { and a free media ( }-2.5 \text { (worst) } \leq \text { Value } \leq+2.5 \text { (best)).[Source: World Governance } \\
\text { Indicators] }\end{array}$ \\
\hline
\end{tabular}


RegQuality

GovEffect

CivilLaw

Anti-Corruption
Reflects perceptions of the government's ability to formulate and implement sound policies and regulations that permit and promote private sector development (2.5 (worst) $\leq$ Value $\leq+2.5$ (best)). [Source: World Governance Indicators]

Reflects perceptions of the quality of public services, the quality of the civil services and the degree of its independence from political pressures, the quality of policy formulation and implementation, and the credibility of the government's commitment to such policies $(-2.5$ (worst) $\leq$ Value $\leq+2.5$ (best)). [Source: World Governance Indicators]

An indicator that equals 1 if a country's legal system is based on civil law, and 0 if common law. [Source: La Porta et al. (1998)]

Corruption Perceptions Index (CPI) that reflects how much a country's public sectors are corrupted $(0$ (most corrupted $) \leq$ Value $\leq+100$ (lease corrupted)). [Source: Heritage Foundation] 